\title{
LIETUVOS KARIUOMENĖS KARININKŲ RENGIMO IR JŲ KVALIFIKACIJOS KĖLIMO RAIDA (1990-2015 M.)
}

\author{
Doc. dr. Feliksas Žigaras \\ Generolo Jono Žemaičio Lietuvos karo akademija
}

Anotacija. Straipsnyje tiriama Lietuvos kariuomenès karininku rengimo ir ju kvalifikacijos kèlimo sistema atkūrus šalies nepriklausomybę: apžvelgiama Lietuvos karininku rengimo pradžia, atskleidžiama Generolo Jono Žemaičio Lietuvos karo akademijos veikla, rengiant karininkus ir ju kvalifikacijos kèlimo galimybes Lietuvoje (pvz., Lietuvos kariuomenès Generolo Adolfo Ramanausko kovinio rengimo centre, Lietuvos kariuomenès Sausumos pajègu Juozo Lukšos mokymo centre, Dr. Jono Basanavičiaus karo medicinos tarnyboje) ir užsienyje.

Pagrindiniai žodžiai: Lietuvos karininkai, Generolo Jono Žemaičio Lietuvos karo akademija, Lietuvos kariuomenès Generolo Adolfo Ramanausko kovinio rengimo centras, Lietuvos kariuomenès Sausumos pajègu Juozo Lukšos mokymo centras, Dr. Jono Basanavičiaus karo medicinos tarnyba, karininku rengimas ir ju kvalifikacijos kèlimas užsienyje, atsargos karininku rengimas.

\section{İvadas}

Tyrimo objektas - Lietuvos kariuomenès karininkų rengimo ir jų kvalifikacijos kèlimo raida (1990-2015 m.).

Tyrimo tikslas - atskleisti Lietuvos kariuomenès karininkų rengimo ir jų kvalifikacijos kẻlimo raidą atkūrus šalies nepriklausomybę.

\section{Tyrimo uždaviniai:}

1. Apžvelgti Lietuvos karininkų rengimo pradžią.

2. Atskleisti Generolo Jono Žemaičio Lietuvos karo akademijos veiklą rengiant karininkus.

3. Aptarti Lietuvos kariuomenės karininkų galimybes kelti kvalifikaciją Lietuvoje ir užsienyje.

Tyrimo metodai - remiantis Lietuvos ir krašto apsaugos sistemos dokumentų, archyvinių šaltinių, mokslinès literatūros, internete publikuotos medžiagos ir periodinès spaudos analize, taikant istorinị ir chronologinị tyrimo metodus, straipsnyje nagrinèjama ir ịvertinama Lietuvos kariuomenès karininkų rengimo ir jų kva- 
lifikacijos kèlimo raida nepriklausomybès metais.

Tyrimo problema - vieno ar kito laikotarpio kariuomenès, jos turètos technikos ir ginkluotès, kariuomenès kaip valdovų ir politikų planų vykdytojos, kaip vienos iš valstybės iškilimo ir nuosmukio svarbiausiujų priežasčių (bent iki dabartinių laikų) pažinimas gali padèti geriau suvokti ir Tautos bei Valstybės istoriją, jos kultūros, mokslo ir technikos, gamybos lygmenį, o karo technika ir ginkluote yra geriausias jų lygmens, krašto ekonomikos atspindys. Tik kariuomenès istorijos pažinimas gali padèti geriau suvokti ir kariuomenès reikšmę dabartinei nepriklausomai Lietuvai, pasirengti giliems ateities netikètumams (Liekis, 2002: 8).

Lietuvos Respublikos krašto apsaugos ministro 2015 m. rugpjūčio 19 d. ịsakymu Nr. V-849 buvo patvirtinta „Lietuvos Respublikos piliečiu rengimo valstybès gynybai strategija“, kurioje teigiama, kad strategijos paskirtis - „numatyti būdus užtikrinti veiksmingą Lietuvos Respublikos Konstitucijoje įtvirtintos piliečių teisès priešintis bet kam, kas prievarta kèsinasi ị šalies nepriklausomybę, jos teritorinị vientisumą ir konstitucinę santvarką, ir jų teisès ir pareigos ginti valstybę nuo užsienio ginkluoto užpuolimo iggyvendinimą.“ Todèl egzistuoja problema, kaip efektyviai paruošti veiksmingą Lietuvos karininkų rengimo sistemą.

\section{Lietuvos karininkų rengimo pradžia}

1990 m. kovo 11 d. paskelbus Lietuvos nepriklausomybę reikejjo ne tik organizuoti krašto apsaugą, bet ir atgaivinti sovietinès okupacijos metais sužlugdytą Lietuvos karininkų rengimą.

1990 m. balandžio 25 d. Lietuvos Respublikos Vyriausybès nutarimu Nr. 125 buvo ikurtas Krašto apsaugos departamentas (KAD). Jo generaliniu direktoriumi paskirtas Aukščiausiosios Tarybos deputatas Audrius Butkevičius. Šio departamento funkcijos buvo saugoti ypač svarbius Lietuvos Respublikos objektus, vykdyti sienų kontrolę.

Atkūrus Lietuvos nepriklausomybę pradèta atkurti Lietuvos kariuomenę. Besikuriančioje krašto apsaugos sistemoje buvo pareiškę norą tarnauti daugiau kaip 1000 karininkų. 1990 m. gegužès 30 d. KAD paskyrus patalpas T. Kosciuškos g. 36, Vilniuje, (doc. dr. A. Vaitkaiti paskyrus KAD generalinio direktoriaus pavaduotoju) iš įvairių miestų pavyko surinkti duomenis apie karininkus, pageidaujančius tarnauti Lietuvos kariuomenèje. Išnagrinèjus duomenis, paaiškëjo, kad 1253 karininkai buvo baigę karo mokyklas, iš jų 398 - baigę karo akademijas, 32 - turejjo mokslo laipsnius ir vardus, dar buvo nemažai karininkų, baigusių aukštąsias mokyklas ir turejjusių leitenanto laipsnị, bet netarnavusių kariuomenèje. Paaiškejjo, kad daugumos atsargos karininkų (išskyrus dimisijos) laipsniai buvo nuo kapitono iki generolo, o tinkamų tarnybai jaunesniujų karininkų - tik 9 (leitenantai ir vyresnieji leitenantai iki 30 metų). Atkuriant Lietuvos kariuomenę, pirmiausia buvo reikalingi būrių vadai. Ši padètis iš dalies susidare todèl, kad prasidejus Sajūdžiui sovietų valdžia jaunus Lietuvos karininkus iš vadinamojo Pabaltijo išsiunte tarnauti ị šalies 
rytus.

Pirmajame KAD karininkų posėdyje (1990 m. birželio 6 d.) buvo išsakyta mintis, kad būtina rengti karininkus, o tam reikèjo įsteigti karo mokyklą arba karininkų rengimo kursus. Ši idèja buvo pateikta KAD generaliniam direktoriui A. Butkevičiui, įvertinus Lietuvoje buvusią sovietų kariuomenę, pritarta minčiai įsteigti karininkų rengimo kursus (1990 m. birželio 11 d.).

Kartu susirūpinta ne tik karininkų, bet ir puskarininkių rengimu. Tą daryti buvo lengviau įkuriant mokomajị batalioną ir šios kategorijos jaunesniujų vadų grandị rengti iš anksčiau sovietų kariuomenejje tarnavusių karių ir šaukiamojo amžiaus vyrų. Reikèjo spręsti klausimus, kur įkurti šias mokyklas, kaip paskirstyti etatus, pareigybes, parengti programas, paskirti vadovus ir sudaryti dèstytojų kolektyvus, numatyti finansavimą, logistiką ir kt.

Po svarstymų ir aptarimų 1990 m. rugpjūčio 7 d. KAD generaliniam direktoriui buvo pristatyti kandidatai i karininkų rengimo kursų viršininko pareigas ir jau po 19 dienų KAD kolegijos posėdyje svarstyti karybos specialistų (karininkų ir puskarininkių) rengimo klausimai, pristatytos pareigūnų i vadovaujamas pareigas ir dėstytojų kandidatūros. Nutarta, kad karininkų kursai turètų pradèti rengti karininkus nuo 1990 metų spalio 1 dienos. Šis karininkų rengimo kursų pradžios laikas pasirinktas dèl numatyto valstybès sienos perėmimo iš sovietų pasieniečių (1991 m. vasario 1 d.). Kitame KAD posėdyje (1990 m. rugpjūčio 29 d.) buvo pateiktas struktūros ir pareigybių projektas, aptarti karininkų rengimo kursų finansavimo klausimai.

Daug kartų buvo grịžtama prie įvairių reikalų svarstymo (dèl patalpų, inventoriaus, mokymo priemonių, ịrangos, programos, trūko dėstytojų specialistų pasieniečių ir vidaus tarnybos). Planuojama mokslo karininkų rengimo kursuose pradžia buvo vis atidedama, o - prie jos vèl grįžtama po ilgų diskusijų (1990 m. spalio 29 ir 31 d. posėdžiai). Tik KAD kolegijos 1990 m. lapkričio 12 d. posėdyje prièmus sprendimą buvo patvirtinti karininkų rengimo kursai, o 1990 m. lapkričio 15 d. pulkininkas B. Vizbaras paskirtas šių kursų viršininku. Sudaryta atestacijos komisija aptarè ir karininkų kursų viršininko pavaduotoju ir Mokymo skyriaus viršininku rekomendavo skirti J. Veselką, viršininko pavaduotoju auklëjamajam darbui - S. Adomonị, pavaduotoju Užnugario (aprūpinimo) tarnybai - V. Latkauską, Finansų tarnybos viršininku - A. Liorentą, Mobazès viršininku - K. Skrinską. Pirmosios laidos karininkus sienos apsaugai ir ịkalinimo įstaigu apsaugai specialistus rengè dèstytojai K. Skrinska, P. Skrivelis, A. Jurevičius, A. Virbila, Ž. Lapènas. Trūko 8 karininkų specialistų (4 - vidaus tarnybos ir 4 - pasienio specialistų).

Siekiant paruošti sumanius, drausmingus, atsidavusius tautos idealams, sugebančius organizuoti vadus, remdamasis 1990 m. gruodžio 20 d. Lietuvos Respublikos Vyriausybès nutarimu Nr. 384 „Dèl Krašto apsaugos departamento karininku kursu organizaciniu klausimu“", Krašto apsaugos departamento generalinis direktorius A. Butkevičius 1990 m. gruodžio 29 d. įsakymu Nr. 45 įsakè: ,1. I steigti Lietuvos Respublikos karininkų kursus; 2. Sporto ir technikos susivienijimo „Vytis“ ge- 
neraliniam direktoriui suteikti Karininkų kursams reikalingas patalpas“, o įsakymo vykdymo kontrolę pavedė Krašto apsaugos departamento generalinio direktoriaus pavaduotojui A. Vaitkaičiui. Taip perkvalifikuoti karininkams Kaune buvo įsteigti Karininkų kursai, o jiems paskirtos patalpos Dariaus ir Girẻno g., Kaune (buvusioje Savanoriškos draugijos armijai, aviacijai ir laivynui remti (DOSAAF) būstinejje). Kursų tikslas - ruošti karininkus krašto apsaugos sistemai.

Studijos prasidèjo $1991 \mathrm{~m}$. sausio 2 d. Tada buvo 72 klausytojai. İ Karininkų kursus buvo priimami Lietuvos piliečiai iki $30 \mathrm{~m}$. amžiaus, savanoriai, turintys sovietų kariuomenės atsargos karininkų laipsnius. Tačiau kursai truko neilgai. Nuo sausio 9 iki vasario 15 kursų klausytojai (I laida) ir personalas Vilniuje gynė Aukščiausiąą Tarybą.

Pirmieji numatyti krašto apsaugos uždaviniai buvo sienų ir ịkalinimo įstaigu apsauga, todèl ir Karininkų kursai pradejo rengti sienų ir ịkalinimo įstaigų apsaugos karininkus.

1991 m. Kursus baige dvi laidos - 194 karininkai, iš jų 24 sienos apsaugos, 18 ịkalinimo ịstaigų apsaugos specialistų, motošaulių, kuopininkų.

1992 m. kovo mèn. Karininkų kursai persikèlè ị savo patalpas tuometèje vairuotojų bazejje Aleksote. Pirmieji metai kursų vadovybei ir personalui buvo nelengvi: specialistus jaunai Lietuvos kariuomenei teko rengti patiems mokantis, kuriant mokymo programas, siekiant sudaryti tinkamas mokymo sąlygas. Mokslas truko 4 mènesius. Kursų klausytojai buvo mokomi ịvairių karinių dalykų, lietuviškų komandų, terminologijos. Baigusiems karininkų kursus buvo suteikiami jaunesniojo leitenanto, leitenanto, vyresniojo leitenanto laipsniai.

Pirmujjų laidų karininkai stojo saugoti valstybės sienų ir ịkalinimo ịstaigų. Kitose Karininkų kursų laidose buvo rengiami motorizuotujų pėstininkų, komendantūrų specialybių karininkai ir kuopininkų specialybės puskarininkiai.

1992 m. Karininkų kursai parenge 273 karininkus, iš jų 141 sienos apsaugos karininką, 120 motošaulių, 12 komendantūrų karininkų ir 140 kuopininkų. Iš viso 413 karių.

Nuo 1993 m. kovo 19 d. Karininkų kursai krašto apsaugos ministro įsakymu Nr. 11 buvo perorganizuoti ị Krašto apsaugos puskarininkių mokyklą. Metu pradžioje buvo išleista paskutinè - 6-oji karininkų laida ir pradètas puskarininkių tarnybos ir mokymo sistemos kūrimo darbas. Tais pačiais metais buvo parengta: pionierių inžinierių - 37, kuopininkų - 17 , motošaulių - 167 , ryšių specialistų- 5 , civilinès saugos specialistų - 113, puskarininkių - 337. Per visą gyvavimo laikotarpị Kursai parengė 470 karininkų (Klenauskienė, Varanavičius, 2015; Kulys, 1995; Surgailis, 2002; Vaitkaitis, 2012, Vizbaras, 1995).

Taigi Karininkų kursuose buvo perkvalifikuojami jaunesnieji atsargos karininkai, praporščikai ir kiti buvę sovietinès armijos karininkai. Tačiau tolesniam karininkų rengimui ir jų kvalifikacijos kèlimui karininkų kursų nepakako. 


\section{1992-ieji: Krašto apsaugos mokyklos įsteigimas}

Krašto apsaugos ministro įsakymu $1992 \mathrm{~m}$. sausio 2 d. buvo pradèta kurti

\section{Lietuvos aukštoji karo mokykla.}

Krašto apsaugos ministerijos 1992 m. vasario 25 d. įsakymu Nr. 112 „Dèl Lietuvos aukštosios karo mokyklos ịkūrimo" nuspręsta ịsteigti aukštają karo mokyklą, kurioje būtų rengiami Lietuvos kariuomenès karininkai.

Lietuvos karo akademijos gimimo diena laikoma 1992 m. birželio 16 d., kai buvo priimtas Lietuvos Respublikos Vyriausybès nutarimas „Dél Krašto apsaugos akademijos steigimo" - buvo leista įsteigti Krašto apsaugos mokyklą, kuri, Aukščiausiajai Tarybai prièmus nutarimą „Dèl Krašto apsaugos akademijos įsteigimo “, turejjo būti reorganizuota ị akademiją.

1992 m. liepos 13 d. krašto apsaugos ministro įsakymu buvo įsteigta Krašto apsaugos mokykla (Vilnius, Šilo g. 5A). I pirmą kursą buvo priimti 154 vaikinai. Būtent ši data yra laikoma sistemingo karininkų rengimo pradžia atkūrus Lietuvos nepriklausomybę.

1992 m. liepos 15 d. buvo patvirtinti mokyklos laikinieji nuostatai. Pagal juos mokykla tapo krašto apsaugos struktūriniu vienetu, pavaldžiu Krašto apsaugos ministerijai. Jai iškeltas uždavinys - rengti specialistus krašto apsaugos sistemai, kelti jų kvalifikaciją. Steigèjo teisès atiteko Krašto apsaugos ministerijai.

Kuriant Krašto apsaugos mokyklą buvo galvojama, kad ateityje ji būtinai taps aukštaja karo mokykla. Todèl formuojant mokyklos struktūrą, buvo laikomasi aukštosios mokyklos principų: steigiamos katedros, leidžiamos mokslinès knygos, vadovèliai.

Pirmuoju Krašto apsaugos mokyklos viršininku laikinai buvo paskirtas plk. Algimantas Vaitkaitis. 1992 m. rugpjūčio 24 d. ji pakeitè Taktikos katedros vyresnysis dėstytojas Jonas Andriškevičius, anksčiau buvęs Vilniaus universiteto karinès katedros viršininku, Savanoriškosios krašto apsaugos tarnybos mokymo centro vadovu, kuriam rugpjūčio $28 \mathrm{~d}$. buvo suteiktas pulkininko laipsnis.

1992 m. rugpjūčio 30 d. krašto apsaugos ministro įsakymu Krašto apsaugos mokyklai įteikta dalinio vèliava, įvyko pirma iškilminga rikiuotè.

1993 m. kovo 13 d. krašto apsaugos ministro įsakymu karininkų, neigijusių karinio išsilavinimo, kvalifikacijai kelti ịsteigtas Neakivaizdinis skyrius. Numatyta bendra studijų trukmè buvo 20 mènesių. Gegužès mèn. mokykloje buvo suformuota pirmoji 25 karininkų neakivaizdininkų grupè.

Lietuvos Respublikos Prezidento 1993 m. spalio 20 d. dekretu Nr. 146 Krašto apsaugos mokyklos viršininkas plk. Jonas Andriškevičius buvo paskirtas Lietuvos Respublikos kariuomenès vadu. Krašto apsaugos mokyklos viršininku tapo plk. dr. Zenonas Kulys.

1993 m. buvo galutinai suformuota Lietuvos kariuomenès struktūra, ịsteigta kariuomenès vado institucija. 


\section{1994-ieji: Lietuvos karo akademijos ịsteigimas ir veikla}

Susidare sąlygos įsteigti aukštesnio lygio karių mokymo įstaigą, kuri rengtu krašto apsaugos sistemai aukščiausios kvalifikacijos specialistus ir galètų jiems suteikti aukštajji išsilavinimą.

1994 m. sausio 18 d. Lietuvos Respublikos Seimo nutarimu buvo ịsteigta Lietuvos karo akademija ir patvirtinta Lietuvos karo akademijos steigiamoji taryba, kurią sudare 35 nariai. Tarybos pirmininku paskirtas krašto apsaugos ministras L. Linkevičius. Krašto apsaugos mokykla buvo reorganizuota ị Lietuvos karo akademiją.

Parengtas Lietuvos karo akademijos statutas, patvirtintas Lietuvos Respublikos Seimo 1994 m. gegužès 26 d. nutarimu Nr. 1-479, kuriame buvo numatyta, kad Lietuvos karo akademija yra aukštoji mokykla - studijų ir mokslo įstaiga, skirta ugdyti Lietuvos kariuomenei aukščiausios kvalifikacijos vadus ir specialistus.

Svarbiausi Akademijos uz̆daviniai:

- rengti Lietuvos Respublikos krašto apsaugos sistemai kvalifikuotus specialistus. Pagal Lietuvos Respublikos Vyriausybès sutartis su kitomis šalimis Akademija gali rengti specialistus ir kitoms šalims;

- rengti mokslininkus, plètoti ir populiarinti fundamentaluji ir taikomaji karo mokslą;

- perkvalifikuoti krašto apsaugos sistemos specialistus karininkus ir kelti jų kvalifikaciją;

- rengti ir leisti mokslo darbus, vadovèlius, mokymo priemones ir kitus leidinius.

Steigiamoji taryba, vadovaudamasi Statutu, 1994 m. birželio 6 d. patvirtino Akademijos struktūrą, etatus, kurie mažai kuo skyrèsi nuo buvusios karo mokyklos etatų ir struktūros, išrinko Karo akademijos rektoriumi plk. dr. Zenoną Kulị ir jo pasiūlymu patvirtino prorektorius: studijoms - plk. dr. Praną Jankauską, mokslui plk. prof. habil. dr. Stasị Puškorių, kariniams reikalams - plk. 1tn. Algimantą Vyšniauską. İsteigtas naujas skyrius - Mokslo centras, liko devynios katedros.

1994 m. lapkričio 29 d. Akademijos mokslininkų susirinkime buvo išrinkta 19 asmenų Lietuvos karo akademijos taryba. Vèliau išrinktas Akademijos senatas.

Čia buvo rengiami dviejų specialybių - sausumos kariuomenès ir pasienio policijos - karininkai. Studijos buvo organizuojamos pakopomis. Akademijoje organizuojamos kariūnų ir neakivaizdininkų studijos. Akademijoje rengiami sausumos kariuomenès, vidaus tarnybos karininkai ir pasienio tarnybos specialistai.

1994 m. liepos 20 d. Akademija išleido pirmają karininkų laidą. 111-ai absolventų buvo suteiktas leitenanto laipsnis.

1995 m. akademijoje atgaivinta prieškario tradicija - suteikti pirmaji karininko laipsni, kardu paliečiant absolvento peti ir ištariant žodžius „Be reikalo nepakelk, be garbès nenuleisk“. Nuo 2009 m. šis priesakas akademijos viršininko isakymu tapo Lietuvos karo akademijos šūkiu. 
Nuo 1995 m. vienąkart per ketvirtį akademijoje leidžiamas atkurtas žurnalas „Kariūnas“, aptariantis Akademijos bendruomenès gyvenimo aktualijas, studijas ir laisvalaikị.

Nuo 1995 m. rugsèjo $1 \mathrm{~d}$. Akademijoje buvo studijuojama pagal čia parengtą bakalauro studijų programą (4 m. mokymas, sudaryta 6400 val. programa), atitinkančią kvalifikacinius aukštojo mokslo reikalavimus.

1997 m. pertvarkytas Neakvyvaizdinis skyrius pradejjo rengti karininkus pagal tą pačią programą. Prasidejjus naujiems mokslo metams buvo pakeista kariūnų pradinio karinio rengimo programa, skiriant 12 savaičių pradinio karinio rengimo programai ir 22 savaites bendroms stažuotems ir lauko pratyboms, pirmą kartą pradèta dèstyti Lietuvos kariuomenès istorija.

Pagal NATO standartus nuolat buvo plètojamas Lietuvos karybos mokslas ir vykdomas karininkų rengimo koncepcijos tobulinimas.

$1998 \mathrm{~m}$. sausio $21 \mathrm{~d}$. buvo įteikti pirmieji bakalauro diplomai 18 karininkų, baigusių antrosios pakopos studijas.

1998 m. gegužès 5 d. Lietuvos Respublikos Seimui prièmus „Lietuvos Respublikos krašto apsaugos sistemos organizavimo ir karo tarnybos įstatyma", Nr. VIII-724, iš esmès pasikeite Akademijos statusas.

Krašto apsaugos ministro įsakymu 1998 m. lapkričio 20 d. Akademijai suteiktas partizanų generolo Jono Žemaičio vardas.

1999 m. ị dienines studijas studijuoti pagal Motorizuotujų šaulių programą pradèta priimti merginas.

1999 m. rugpjūčio 10 d. Lietuvos Respublikos Vyriausybė nutarimu Nr. 896 patvirtino naują Lietuvos karo akademijos statutą, vèliau priimamos kelios naujos statuto redakcijos. Nustatyta, kad čia studijuoja trijų kategorijų kariai: kariūnai, karininkai klausytojai ir klausytojai. Be to, čia vykdomas Vilniaus aukštųjų mokyklų studentų karinis rengimas.

Akademijos tikslas - rengti ginkluotosioms pajègoms vadus-lyderius, puoselejjant Lietuvos kariuomenès tradicijas, teikiant kokybišką universitetinị ir karini išsilavinimą, vykdant mokslinius tyrimus (LKA statutas, 2003).

Svarbiausi Akademijos uždaviniai pagal LKA statutą (2003) yra šie:

- rengti Lietuvos Respublikos krašto apsaugos sistemai kvalifikuotus karininkus - karinių vienetų vadus ir krašto apsaugos sistemai reikalingus štabų jaunesniuosius karininkus - ir suteikti jiems aukštaji išsilavinimą;

- $k e l t i$ Lietuvos ir kitų valstybių karininkų kvalifikaciją.

Igyvendindama savo uždavinius, Akademija ugdo studijuojančiųų vadovavimo ịgūdžius ir naujausioms technologijoms ir kultūros vertybèms imlią asmenybę pagal humanistinių ir tautinių vertybių, pilietiškumo, kultūros ir visapusiško asmenybės ugdymo principus (LKA statutas, 2003).

Karo akademija yra vienintelè aukštoji mokykla Lietuvoje, kurioje ugdomas kovotojo tipas - lyderis, kuriuo besąlygiškai pasitikètų ir būsimieji kariai, ir tauta. Akademija nuolat modernizuojama. 
2000 m. vasario 23 d. Lietuvos karo akademijos viršininku paskirtas plk. Algis Vaičeliūnas. Siekiant rengti karininkus pagal NATO valstybių metodiką ir keliamus reikalavimus, reikèjo iš esmès pertvarkyti Lietuvos karo akademiją, prasidejjo reformos. Joms igyvendinti ministras Č. Stankevičius 2000 m. kovo 10 d. sudare darbo grupę, vadovaujamą paties Akademijos viršininko. Buvo parengta plètros iki 2003 metų programa, pagal kurią turèjo būti pertvarkyta jos struktūra ir etatai, tobulinamos karinio rengimo programos, kad jos atitiktų NATO šalyse keliamus reikalavimus, parengtos naujos akademinių studijų programos, plètojama Akademijos infrastruktūra taip, kad būtų užtikrintos geresnès kariūnų ir karininkų mokymosi ir buities sąlygos.

Vienas iš esminių reformos žingsnių - atskirti karinị ir universitetinị rengimą. Buvo nuspręsta nuo $2001 \mathrm{~m}$. vietoje vienos karybos bakalauro programos rengti pagrindines I pakopos ketverių metų studijas pagal Viešojo administravimo, Vadybos ir tarptautinių santykių (politikos mokslų) studijų programas. Karinio rengimo programa, kurią išeina visi kariūnai, skirta motorizuotųu pėstininkų būrio vadui.

$2001 \mathrm{~m}$. vasario mèn. sukurta nauja Akademijos struktūra, kurioje išskirtos 4 dalys: 3 karinès ir 1 universitetinè, taip pat vèl ịsteigtas Mokslo centras, nes Lietuvos karo akademijai tapus universitetine aukštąja mokykla, reikejjo plètoti mokslinị darbą. Akademijos mokslininkų darbų temas tvirtina krašto apsaugos ministras. Mokslinis darbas buvo pletojamas trimis pagrindinėmis kryptimis - tai strateginiai tyrimai, moderniujų technologijų taikymas karybje, karo istorija.

Kartu su Vilniaus universiteto Tarptautinių santykių institutu gruodžio mènesị ịsteigtas Strateginių tyrimų centras, su Vytauto Didžiojo universitetu - Karo istorijos centras. Birželio mènesị įkurta Politikos mokslų katedra.

$2001 \mathrm{~m}$. Lietuvos ordinaro dekretu Lietuvos karo akademijoje ịsteigta koplyčia, jai suteiktas vyskupo ir bažnyčios mokytojo šv. Anzelmo vardas.

2011 m. įsteigtas Lietuvos karo akademijos Universitetinių studijų institutas (USI) organizuoja universitetines studijas Lietuvos Respublikos krašto apsaugos sistemos kariams, kariūnams, valstybès tarnautojams ir darbuotojams, dirbantiems pagal darbo sutartis, kitų Lietuvos Respublikos institucijų, sudariusių bendradarbiavimo sutartis su Krašto apsaugos ministerija, pareigūnams ir užsienio šalių kariams, koordinuoja ir kontroliuoja studijų ir kursų eigą, planuoja USI veiklą koordinuojant su Lietuvos karo akademija ir kitais krašto apsaugos sistemos padaliniais.

USI uždaviniai - planuoti, vykdyti, koordinuoti, kontroliuoti universitetines studijas ir vykdyti mokslinius tyrimus. USI vadovauja ir koordinuoja Akademijos Vadybos, Politikos, Inžinerinès vadybos, Humanitarinių mokslų, Užsienio kalbų katedrų veiklą.

Karini rengima vykdo Baziniai karininku kursai. 2016 m. vasario 1 d. duomenimis Akademijoje dèstè (tarnavo) 16 profesorių, 22 docentai, 31 lektorius, 49 instruktoriai.

Akademijoje sėkmingai vyksta bakalauro (nuo 1995 m.), magistrantūros (nuo 2002 m.) ir doktorantūros (nuo 2012 m.) studijos. 
Būsimieji karininkai Lietuvos karo akademijoje studijuoja pagal tris socialinių mokslų srities bakalauro studiju programas: Tarptautinių santykių, Gynybos ir saugumo institucijų valdymo, Moderniujų gynybos technologijų vadybos. Nuo 2016-2017 mokslo metų Akademija pradės vykdyti ketvirtają socialinių mokslų srities pirmosios pakopos (bakalauro) studiju programą - Nacionalinio saugumo ir gynybos, kurioje karybos mokslai bus formalūs ir sudarys maždaug pusę studijų laiko. Planuojama, kad ir kitose programose palaipsniui atsiras daugiau karybos.

\section{Bakalauro studijos:}

\section{Gynybos ir saugumo institucijų valdymas}

Studijų trukmè. $3,5 \mathrm{~m}$. universitetinių studijų ir karinio rengimo ir $0,5 \mathrm{~m}$. tik karinio rengimo.

Suteikiama kvalifikacija ir karinis laipsnis. Viešojo administravimo bakalauras ir leitenanto laipsnis.

Tikslas. Suteikti žinių ir suformuoti igūdžius, būtinus gynybos ir saugumo institucijų funkcinèms sritims ir sąveikai suprasti, analizuoti, vertinti.

Paskirtis. Studijų sritis - socialiniai mokslai, kryptis - viešasis administravimas, programos vykdymo kalba - lietuvių.

\section{Moderniųjų gynybos technologijų vadyba}

Suteikiama kvalifikacija ir karinis laipsnis. Vadybos bakalauras ir leitenanto laipsnis.

Tikslas. Parengti krašto apsaugos sistemoje naudojamų technologijų vadybos specialistus, turinčius išsamių žinių, gebejjimų ir ịūdžių karinès ginkluotès, informacinių technologijų ir transporto srityse, suvokiančius grẻsmes valstybės saugumui ir suprantančius karinių technologijų panaudojimo politinę aplinką, sugebančius suprasti sudètingų sistemų kūrimo ir veikimo procesus, šiuolaikiškai spręsti civilinio ir karinio transporto ir logistikos problemas įvairiose Lietuvos organizacijose ar įmonèse.

Absolventas turi išmanyti pagrindines vadybos teorijas, ekonomikos dèsnius, mokèti naudotis naujausiomis informacinèmis technologijomis, gebėti analizuoti organizacijų ir verslo įmonių veiklos problemas, mokèti taikyti moksliškai pagrịstus įmonių veiklos ir rinkos tyrimų metodus; mokèti planuoti karinès organizacijos padalinio veiklą ir tinkamai panaudoti tiek materialius, tiek žmogiškuosius išteklius.

Paskirtis. Studijų sritis - socialiniai mokslai, kryptis - vadyba, pakopa - pirmoji, programos vykdymo kalba - lietuvių. 


\section{Nacionalinis saugumas ir gynyba (nauja studijų programa)}

Studijų trukmė. $4 \mathrm{~m}$. universitetinių studijų ir karinio rengimo.

Suteikiama kvalifikacija ir karinis laipsnis. Visuomenès saugumo bakalauras ir leitenanto laipsnis.

Tikslas. parengti karininkus, aukštos kvalifikacijos nacionalinio saugumo ir karybos specialistus, išmanančius vidaus ir išorès visuomenès saugumo grèsmes ir iššūkius, gebančius juos analizuoti ir priimti bei iggyvendinti pagrįstus sprendimus, igijusius tarpdisciplininių žinių ir įgūdžių, būtinų vadovauti LR kariuomenès padaliniams taikos, krizės ir karo metu tarnaujant Lietuvos valstybei.

Paskirtis. Studiju sritis - socialiniai mokslai, kryptis - visuomenès saugumas, pakopa - pirmoji, programos vykdymo kalba - lietuvių.

\section{Tarptautiniai santykiai}

Studijų trukmè. $3,5 \mathrm{~m}$. universitetinių studijų ir karinio rengimo ir $0,5 \mathrm{~m}$. tik karinio rengimo.

Suteikiama kvalifikacija ir karinis laipsnis. Politikos mokslų bakalauras ir leitenanto laipsnis.

Tikslas. Parengti politikos mokslų specialistus, išmanančius Lietuvos ir kitų valstybių politinių sistemų struktūrą ir sprendimų prièmimo procesus, gebančius taikyti pagrindines politikos mokslų, tarptautinių santykių, saugumo ir karo teorijas analizuojant tarptautinio ir nacionalinio saugumo problemas, pagrindines Lietuvos užsienio, saugumo ir gynybos politikos raidos tendencijas, regioninès politikos ir geopolitinius pokyčius ir gebančius taikyti moksliškai pagrịstus nacionalinès ir užsienio saugumo ir gynybos politikos tyrimų metodus. Siekiama ugdyti pilietiškus ir pasiryžusius ginti Tèvynę, patriotines, demokratines vertybes ir toleranciją demonstruojančius specialistus, gebančius savarankiškai analizuoti šiuolaikines grèsmes, saugumo iššūkius, savarankiškai veikti kintant aplinkai, spręsti civilių ir kariu bendradarbiavimo problemas ir iššukius.

Paskirtis. Studijų sritis - socialiniai mokslai, kryptis - politikos mokslai, pakopa - pirmoji, programos vykdymo kalba - lietuvių.

\section{Magistrantūros studijos:}

\section{Karinė diplomatija}

Antrosios pakopos studijose gali mokytis profesinès karo tarnybos kariai, gavę LR krašto apsaugos ministro leidimą ir pagal Krašto apsaugos ministerijos susitarimus su kitomis valstybės institucijomis kitų valstybės institucijų valstybės tarnautojai.

Studijų trukmè. $2 \mathrm{~m}$.

Suteikiama kvalifikacija. Politikos mokslų magistras.

Tikslas. Antrosios pakopos universitetinių karinès diplomatijos (politikos 
mokslų) studijų programos paskirtis yra parengti dviejų ir daugiau metų tarnybos Lietuvos kariuomenejje patirti turinčius karininkus kaip politikos mokslų magistrus - kompetentingus profesionalus, pasirengusius kvalifikuotai dirbti krašto apsaugos sistemos pletojamame tarptautiniame bendradarbiavime, dalyvauti tarptautinèse misijose ir gebančius vertingai išnaudoti tarptautinio bendradarbiavimo galimybes.

Siekiama, kad studijas baigęs absolventas žinotų pagrindines politikos mokslų ir tarptautinių santykių sąvokas ir teorines prieigas, svarbiausius savo ir kitų valstybių politikos ir istorijos faktus, išmanytų savo ir kitų šalių politinių institucijų bei reikšmingiausių tarptautinių organizacijų funkcionavimo principus ir taisykles; gebètų rinkti, sisteminti ir vertinti informaciją ir galiausiai gebètų savarankiškai atlikti tarptautinių politinių reiškinių analizę ir vertinimą.

Akademijos magistrantai, visų pirma, yra rengiami tarnybai Lietuvos krašto apsaugos sistemoje. Sékmingai studijas baigusiu absolventu igytas politikos mokslų magistro laipsnis tampa rimta prielaida tolesnei karininko karjeros sèkmei (tarnyba tarptautinèse taikos palaikymo misijose, darbas tarptautiniuose kariniuose štabuose, karo ataše tarnyba ir kt.), o taip pat atveria kelią siekti akademinio daktaro laipsnio tiek politikos, tiek ir gretutinėse socialinių mokslų srities kryptyse.

Pagaliau Akademijoje igyjamas politikos mokslų magistro laipsnis atlieka ir tam tikrą karininkų socialinės apsaugos funkciją. Jeigu dẻl vienokių ar kitokių priežasčių (sveikatos sutrikimų, nelaimingų atsitikimų ir pan.) karininkas negalètų tęsti tarnybos ir siekti karjeros, Akademijoje igyta kvalifikacija suteiktu galimybę ieškotis vidaus ir užsienio saugumo politikos analitiko, projektų vadovo ar specialisto darbo civiliniame sektoriuje.

Paskirtis. Studiju sritis - socialiniai mokslai, kryptis - politikos mokslai, pakopa - antroji, programos vykdymo kalba - lietuvių.

\section{Visuomenès saugumas ir gynyba}

Antrosios pakopos studijose gali mokytis tik profesinès karo tarnybos kariai gavę LR krašto apsaugos ministro leidimą.

Studijų trukmè. $2 \mathrm{~m}$.

Suteikiama kvalifikacija. Visuomenès saugumo magistras.

Tikslas. Rengti kompetentingą, kritiškai mąstantị karininką, statutinių institucijų darbuotoją, išmananti giluminius visuomeninius procesus, šiuolaikinės visuomenès raidos tendencijas nacionalinio saugumo kontekste, nacionalinio saugumo politikos pagrindus, gebantị analizuoti grésmes nacionaliniam saugumui ir kūrybiškai spręsti nacionalinio saugumo strategijos ir gynybos įgyvendinimo uždavinius.

Paskirtis. Studijų sritis - socialiniai mokslai, kryptis - visuomenès saugumas, pakopa - antroji, programos vykdymo kalba - lietuvių, anglų. 


\section{Žmonių išteklių vadyba}

Antrosios pakopos studijose gali mokytis tik profesinès karo tarnybos kariai, gavę LR krašto apsaugos ministro leidimą.

Studijų trukmè. $2 \mathrm{~m}$.

Suteikiama kvalifikacija. Žmonių išteklių vadybos magistras.

Tikslas. Rengti plačios erudicijos ir kompetentingus žmonių išteklių vadybos specialistus, gebančius savitai ir savarankiškai plètoti ir igyvendinti naujausiomis mokslo teorijomis ir tyrimais pagrịstus organizacijų plètros sprendimus, susijusius su žmonių ištekliais.

Paskirtis. Studijų sritis - socialiniai mokslai, kryptis - viešasis administravimas, pakopa - antroji, programos vykdymo kalba - lietuvių.

\section{Politikos mokslų doktorantū ros studijos}

Vytauto Didžiojo universiteto senato $2011 \mathrm{~m}$. birželio 28 d. nutarimu Nr. 5-28 buvo patvirtintas Vytauto Didžiojo universiteto su Generolo Jono Žemaičio Lietuvos karo akademija, Kauno technologijos universitetu ir Klaipėdos universitetu politikos mokslų krypties mokslo doktorantūros reglamentas (toliau - Reglamentas), parengtas pagal Lietuvos Respublikos Vyriausybės 2010 m. gegužès $12 \mathrm{~d}$. nutarimu Nr. 561 patvirtintus Mokslo doktorantūros nuostatus.

Šis Reglamentas nustato doktorantūros studijų, doktoranto mokslinių tyrimų, disertacijos rengimo, gynimo ir mokslo daktaro laipsnio suteikimo tvarką Vytauto Didžiojo universitete su Generolo Jono Žemaičio Lietuvos karo akademija, Kauno technologijos universitetu ir Klaipėdos universitetu (toliau vadinamos - Doktorantūros institucijos) politikos mokslų kryptyje, kurioje joms kartu Lietuvos Respublikos švietimo ir mokslo ministerija suteikè doktorantūros teisę.

Doktorantūros paskirtis - rengti mokslininkus, gebančius savarankiškai atlikti mokslinių tyrimų ir eksperimentinès (socialinès, kultūrinès) plètros darbus ir spręsti mokslo problemas. Doktorantūra ją baigusiam ir mokslo daktaro laipsnị igijusiam asmeniui turi užtikrinti pakankamą kompetenciją pažangiausių tiriamojo darbo, mokslo sričių ir jų sąveikos žinių; specializuotų gebẻjimu ir metodikų mokslinių tyrimų ir kitų sričių problemoms spręsti, turimoms žinioms ar profesinei praktikai plèsti; gebẻjimą dirbti savarankiškai, mokslo ir profesijos išmanymą naujoms idejoms ar procesams kurti bei panaudoti studijose ir kitoje veikloje.

Mokslo daktaro laipsnis gali būti suteikiamas asmeniui, kuris sėkmingai baigè nuolatinès (iki 4 metų) arba ištęstinès (iki 6 metų) formos doktorantūrą, parengè disertaciją ir ją apgynè, arba asmeniui, kuris apgynė eksternu parengtą disertaciją.

I Politikos mokslų krypties doktorantūrą asmenys priimami atviro konkurso būdu atskirai ị kiekvienos doktorantūros teisę igijusios partnerinès institucijos doktorantūrą pagal pasirinktą tematiką. Stojantysis gali pretenduoti ne daugiau kaip i dvi skirtingas tematikas.

Konkursą organizuoja administruojančio Vytauto Didžiojo universiteto 
Mokslo tarnyba, konkursą vykdo Politikos mokslų krypties doktorantūros komitetas (toliau - Komitetas) prièmimo sąlygose nustatyta tvarka.

\section{Kvalifikaciniai reikalavimai:}

- Magistro kvalifikacinis laipsnis arba jam prilygintas aukštasis išsilavinimas.

- Mokslinè patirtis, dalyvavimas mokslineje veikloje.

2015 m. Lietuvos karo akademijos Politikos mokslų katedroje doktorantūroje studijavo penki doktorantai.

2003 m. pagal Akademijos plètros programą atskirti karinis rengimas ir akademinès studijos; Akademijoje ịvestas karininko (lyderio) ugdymas, kuris buvo integruotas ị karinio ugdymo sistemą. Tai nuoseklus mokymas, ugdantis būsimojo būrio vado lyderio savybes, formuojantis demokratišką pilietinę pasaulejautą. Programos tikslas - parengti karininką, pasižyminti gerais pedagoginiais sugebėjimais, kuris ne tik perduotų žinias savo kariams, bet ir atliktų auklètojo, ugdytojo vaidmenị. Kariūnų bataliono struktūra yra taip sudaryta, kad kiekvienas kariūnas iggytų kiek galima daugiau vadovavimo ịgūdžių. Be to, kariūnai pagal bakalauro studijų programą atlieka praktiką Lietuvos valdžios ir valdymo institucijose, privačiose verslo įmonėse.

Krašto apsaugos ministro $2008 \mathrm{~m}$. gegužès $8 \mathrm{~d}$. įsakymu Nr. V-398 buvo patvirtinta Akademijos plètros programa, kurios tikslas - pertvarkyti karinị rengimą ir universitetinį studijų organizavimą. Programos prioritetinès sritys yra šios: pirmosios ir antrosios universitetinių studijų ir karinio rengimo pakopų pertvarkymas siekiant užtikrinti kvalifikuotą ir efektyvų karininkų rengimą. Akademijos personalo ir visų veiklos sričių optimizavimas siekiant efektyviai panaudoti žmogiškuosius, finansinius, materialinius ir kitus institucijos išteklius.

2008-2009 mokslo metais keitėsi Akademijos struktūra. Sukurtos naujos struktūrinès grupès: Lyderio ugdymo grupè, Karinio rengimo grupè, Mokslo ir studiju grupè, Paramos grupè, kurios sujungè anksčiau buvusius padalinius.

Krašto apsaugos ministro $2011 \mathrm{~m}$. liepos 8 d. įsakymu Nr. V-774 buvo patvirtinta nauja Akademijos struktūra: panaikintos Lyderio ugdymo, Karinio rengimo, Mokslo ir studijų ir Paramos grupès, pervadinti S1, S2/S3, S4/S6, S5 skyriai, išplėstas Studijų skyrius, sukurtas Sausumos pajègų, štabo karininkų kursų skyrius, panaikinta vyresniojo teisininko pareigybė, Atrankos centras perduotas Štabo viršininko pavaldumui.

Krašto apsaugos ministro $2013 \mathrm{~m}$. įsakymu Nr. V-835 buvo patvirtinta nauja Akademijos struktūra: panaikinta Taikomujų mokslų katedra, pervadintos Taktikos ir ginkluotės bei Kovinès paramos ir kovinio aprūpinimo sekcijos, išplèstas Bazinių karininkų skyrius sukuriant Jaunesniujų karininkų vadų mokymo sekciją. Kariūnų batalione panaikintas Sporto centras ir sukurti Fizinio rengimo ir sporto bei Lyderio ugdymo skyriai. Užsienio kalbų katedra perduota Universitetinių studijų instituto pavaldumui.

Akademijoje karinį rengimą vykdo Baziniai karininkų kursai (BKK), kurių tikslas - parengti karininkus (būrių vadus, karininkus aviacijos specialistus ir karininkus specialistus) Lietuvos kariuomenei ir jos rezervui, gebančius vykdyti savo 
pareigas ir atlikti užduotis taikos ir kovinių veiksmų metu. Ugdyti vado lyderio savybes ir vertybes, suteikti būsimiems karininkams teorinių žinių ir praktinių ịūdžių, būtinų vadovauti būriui ar eiti kitas tolygias pareigas.

\section{Pagrindiniai BKK uždaviniai:}

- rengti būrių vadus, atitinkančius krašto apsaugos ministro patvirtintus kvalifikacinius reikalavimus, vadovaujantis karininko bazinio rengimo programa;

- rengti karininkus aviacijos specialistus vadovaujantis bazinio oro pajėgu karininkų karinio rengimo programa;

- rengti karininkus specialistus vadovaujantis atitinkamomis kursų programomis;

- vesti pratybas rezervo būriu vadams ir valstybės tarnautojams, vadovaujantis atitinkamomis kursų programomis;

- padèti vesti pratybas, teikti paramą mokymo klausimais kitiems LKA padaliniams, Lietuvos kariuomenès vienetams ir Šaulių sajungai;

- vykdyti LKA profesinès karo tarnybos karių karinị rengimą.

BKK sudaro Taktikos sekcija, Kovinès paramos sekcija, Kovinio aprūpinimo sekcija ir Jaunesniujų karininkų vadų mokymų sekcija. BKK pavaldūs Karinio rengimo grupès viršininkui.

Pèstininkų bürio vado rengimas organizuojamas pagal 9 modulius: I modulis - pagrindinių karinių žinių igijimas ir pėstininkų individualus rengimas (1 kursas); II modulis - skyriaus rengimas ir teorinių žinių igijimas (2 kursas); III modulis - mūšio funkcijos būrio lygmeniu (3 kursas); IV modulis - šaudymo vadovo (I-III etapai), ugnies koreguotojo kursai ir taktikos pagrindai (3 kursas); V modulis - pėstininkų būrys patruliavime ( 3 kursas); VI modulis - pėstininkų būrys puolime (4 kursas); VII modulis - pėstininkų būrys gynyboje (4 kursas); VIII modulis - mūšis mieste (4 kursas); IX modulis - taikos rèmimo operacijos (4 kursas).

Sèkmingai baigęs būrio vado rengimą karininkas turi gebėti vadovauti būriui, išmanyti mūšio vedimo eigą, gerai organizuoti ir vesti pratybas kariams, išmanyti būrio ginkluotès ir technikos taktinio panaudojimo galimybes, gebėti taikyti pagrindinius kovinès paramos ir kovinių aprūpinimo padalinių aprūpinimo principus.

Sèkmingai baigęs pėstininkų būrio vado karinị rengimą ir išlaikęs kvalifikacinị egzaminą kariūnas ịgyja pėstininkų būrio vado kvalifikaciją. Be to, kariūnams suteikiama šaudymo vadovo (I-III etapų) kvalifikacija, fizinio rengimo instruktoriaus kvalifikacija, pirmosios medicininès pagalbos pažymejjimas, aplinkos apsaugos pažymèjimas, darbo saugos pažymėjimas ir nustatomas anglų kalbos mokejjimo lygis.

Akademijoje ivairiu lygiu karininku kvalifikacijos kèlima rengia: Rezervo būrių vadų kursai, Karininkų specialistų pagrindinio karinio parengimo kursai, Vadų ir jaunesniujjų štabo karininkų kursai, Vytauto Didžiojo karininkų kursai, Oro pajègų štabo karininkų kursai, Karinių oro pajėgų jaunesniujų karininkų kursai (www.lka.lt).

Lyderio ugdymo sistema. Viena iš prioritetinių veiklos krypčių Lietuvos ka- 
riuomenèje yra vado lyderio savybių ir jo profesiniu igūdžių ugdymas. Siekiant tobulinti bazini karini rengimą ir suaktyvinti mokslo tiriamaji darbą šioje srityje, krašto apsaugos ministro ịsakymu nuo $2006 \mathrm{~m}$. balandžio $3 \mathrm{~d}$. Lietuvos karo akademija pradejjo igyvendinti vieną iš moderniausių ir ilgalaikių Lietuvos kariuomenès projektų - mokslo tiriamaji darbą „Lyderystè ir jos įtaka vado lyderio ugdymui“".

„<...>Valstybes mastu Lietuvos karo akademija yra lydere praktinio lyderio ugdymo srityje. Karo akademija ugdo vadus, kurie sudètingoje situacijoje sugebès savarankiškai priimti valstybei svarbius sprendimus, gebès įtikinti ir įkvèpti, rüpinsis savo pavaldiniais, bus profesionalūs, sieks tobulèti, kad bütu laiku, tiksliai ir kūrybingai ịvykdytos skirtos užduotys.

Lyderio ugdymas yra grindžiamas visu Karo akademijos padaliniu ir kiekvieno asmenine atsakomybe ir pareiga. Bendra atsakomybe yra suprantama taip, kad kiekvienas Karo akademijos bendruomenès narys savo elgesiu, profesionalumu ir pilietiškumu sudaro ta aplinka, kurioje kariünas mokosi, bręsta ir tobuleja. Kiekvieno Karo akademijos bendruomenès nario pareiga büti asmeniniu sektinu pavyzdžiu kariūnui.

Lyderystès ugdymas Karo akademijoje orientuotas $i$ kompetenciju, reikalingu vadui vadovauti, ryžtingai ir kūrybingai veikti, prisiimti atsakomybę, rūpintis pavaldiniais, ugdyma.

Lyderystès kompetenciju ugdymas Karo akademijoje apima ir teoriniu žiniu suteikima, ir praktini psichofizini lavinima. Praktinis lyderystès ugdymas apima potyrio užsiemimus, skirtus geriau suprasti ir reflektuoti savo elgsena ir laikysena, viešojo kalbèjimo ir viešu diskusiju gebejjimu lavinimo užsièmimus, temines ugdomąias išvykas, geresniam tautos ir valstybès svarbiu objektu ir ịvykiu pažinimui.

Strategineje perspektyvoje Karo akademija lyderystès ugdymo procesa sieks remti objektyviais Lietuvai büdingais tyrinejjimais, kurs pamatinèmis vertybèmis ir kompetencijomis grista profiliavimo, profesinio orientavimo sistema $<\ldots>$ ". (Generolo Jono Žemaičio Lietuvos karo akademijos strategija 2013-2018).

Akademija, bendradarbiaudama su Vilniaus Gedimino technikos universiteto Antano Gustaičio aviacijos institutu, Karinèms oro pajėgoms rengia orlaivių pilotus, skrydžių vadovus ir aviacijos mechanikos ir elektronikos inžinierius. Kariūnai Antano Gustaičio aviacijos institute studijuoja pagal penkias technologijos mokslu srities studijų programas: bakalauro - Aviacijos mechanikos inžinerijos, Elektronikos inžinerijos, Automatikos, ir magistrantūros - Orlaivių pilotavimo ir Skrydžių valdymo.

Nuo 2012-2013 mokslo metų LKA kartu su Lietuvos aukštaja jūreivystės mokykla (Klaipėdoje) ir Karinėmis jūrų pajègomis vykdo bazini jūrų pajègų karininkų rengimą. Kariūnams, įstojusiems ị LKA Moderniujų gynybos technologijų vadybos studiju programą ir po pirmo semestro Akademijoje perèjusiems atranką, suteikiama galimybė studijuoti Lietuvos aukštojoje jūreivystės mokykloje pagal dvi technologijos mokslų srities bakalauro studijų programas - Jūrų laivavedybos ir Laivų energetinių ịrenginių eksploatavimo. Karinị rengimą kariūnai tęsia Karinių 
jūrų pajègų Mokymo centre Klaipèdoje.

Lietuvos karo akademiją sèkmingai baigusiems kariūnams suteikiamas pirmasis karininko (leitenanto) laipsnis, bakalauro ir būrio vado kvalifikacijos. Paprastai jie skiriami ị būrio vado pareigas Lietuvos kariuomenès daliniuose.

Akademijoje vyksta intensyvus ir turiningas mokslinis, metodinis darbas; dažnai organizuojamos konferencijos, seminarai; dalyvaujama šalies ir tarptautiniuose projektuose ir kt.

Lietuvos karo akademijoje mokslinius tyrimus koordinuoja Karo mokslų institutas (KMI), kurio tikslas - koordinuoti mokslo darbą LKA ir vykdyti aktualius KAS strateginių tyrimų, karo istorijos, karo technologijų, karo mokslų ir karo teorijos sričių mokslo darbus.

\section{Pagrindiniai KMI uždaviniai:}

- koordinuoti mokslo darbą LKA atliekant krašto apsaugos sistemai ir LKA aktualius mokslinius tyrimus;

- padèti organizuoti katedru mokslo darbus;

- atlikti mokslo darbų, teikiamų Krašto apsaugos ministerijai, ekspertizes;

- vykdyti mokslo darbus pagal savo kompetenciją.

Lietuvos karo akademijos Karo mokslų institutą sudaro Strateginių tyrimų, Karo istorijos ir Karo technologijų centrai. Karo mokslų institutas įsteigtas 2010 m. rugpjūčio 10 d. LKA Mokslo centro pagrindu. Mokslo centras buvo ịsteigtas $1994 \mathrm{~m}$. birželio $4 \mathrm{~d}$. Jis organizavo mokslines konferencijas, rengè mokomuosius leidinius. Dėl karybos mokslo tyrimų užsakymų stokos Mokslo centras veikè su pertrūkiais - 1998 m. buvo panaikintas, o 2001 m., igyvendinant Akademijos reformą, vèl atkurtas.

Karo mokslų instituto mokslinė veikla apima keletą krypčių:

Moderniujų technologiju kryptis (Karo technologijų centras, Inžinerinès vadybos katedra):

- Aviacinio ir kito alternatyvaus kuro panaudojimo galimybių Lietuvos kariuomenès sausumos transporto priemonèse tyrimas;

- Šiuolaikinių technologijų pritaikymo karinėms reikmėms tyrimai;

- Naujų galimų - potencialiai sprogstamujų medžiagų modeliavimas ir jų savybiu teorinis ir eksperimentinis tyrimas kvantmechaniniais metodais. katedra):

Strateginiu tyrimu kryptis (Strateginiu tyrimu centras, Politikos mokslu

- Lietuvos euroatlantinès integracijos politinių ir gynybinių aspektų modeliavimas ir tyrimai;

- mokslo leidinys „Lietuvos metinė strateginè apžvalga“;

- Lietuvos Rytų kaimynų karinès, politinès ir ekonominès raidos tendencijos;

- visuomenès nuomonès apie aktualias krašto apsaugos sistemos plètros problemas tyrimai.

Karo istorijos tyrimu kryptis (Karo istorijos centras):

- Lietuvos karybos istorija (tyrimai ir analizè); 
- mokslo leidinys „Karo archyvas“.

\section{Kiti mokslo tiriamieji darbai (Vadybos katedra, Humanitariniu mokslu ka- tedra, Užsienio kalbu katedra):}

- mokslo leidinys ,Journal of Security and Sustainability Issues“;

- projektas „Pilietinè visuomenė ir nacionalinis saugumas: Lietuvos krašto apsaugos sistemos vaidmuo jaunimo pilietinio ugdymo procese“;

- „Kariūnų intensyvaus ir efektyvaus užsienio kalbų mokymo bei išmokimo modulio dimensija“" (www.lka.lt).

Akademijos mokslininkai ir pedagogai 1992-2014 m. parengè daugiau kaip 400 ịvairių sričių monografijų, mokslo studijų, žodynų, žinynų, vadovẻlių, mokomujjų ir metodinių priemonių, mokslinių konferencijų pranešimų rinkinių ir kitų leidinių. Kiekvienais metais lietuvių ir anglų kalbomis išleidžiama Lietuvos metine strateginė apžvalga, Akademijos mokslo žurnalo „Karo archyvas“ tomas ir kt. Akademijos bibliotekos fonduose saugoma daugiau kaip 250 tūkst. egz. leidinių.

Akademijos Užsienio kalbų institute (UKI), ịkurtame 2006 m. rugsèjo 22 d., organizuojami anglų kalbos kursai, kurių tikslas - mokyti anglų kalbos krašto apsaugos sistemos karius, valstybės tarnautojus ir pagal darbo sutartis dirbančius darbuotojus, kitų Lietuvos Respublikos statutinių institucijų pareigūnus, taip pat užsienio valstybių karininkus, kurie turès dalyvauti daugiatautėse NATO, JT ar ES misijose ir operacijose, kelti kvalifikaciją užsienio valstybėse ar vykdyti pareigines funkcijas ir užduotis, kurioms atlikti reikalingos labai geros anglų kalbos žinios.

UKI apima Vilniaus anglų kalbos mokymo ir Kauno anglų kalbos mokymo skyrių. UKI organizuojami tarptautiniai anglų kalbos kursai, bazinio lygio anglų kalbos kursai, antro lygio anglų kalbos kursai, trečio lygio anglų kalbos kursai, bazinio, antro ir trečio lygio anglų kalbos kartojimo kursai, anglų kalbos kursai pagal JAV tarptautinę karinio mokymo programą, specializuoti anglų kalbos kursai. Nuo 2005 m. pradžios iki 2013 m. rugsèjo mèn. kursus yra baigę 4200 klausytojų ir 69 užsienio valstybių karininkai.

Kursus veda didžiulę patirtį turintys anglų kalbos dėstytojai, kurie stengiasi padèti kiekvienam klausytojui ịveikti iškylančias anglų kalbos mokymosi problemas. Prieš kursų pabaigą vedama klausytojų anketinė apklausa, kuria ịvertinamas kiekvieno dèstytojo darbas su klausytojais.

Nuo 1992 m. iki 2016 m. Lietuvos karo akademijai vadovavo 10 viršininkų: plk. Algimantas Vaitkaitis (laikinai ejjo pareigas) (1992-02-21-1992-08-28), plk. Jonas Andriškevičius (1992-08-24-1993-10-25), brg. gen. Zenonas Kulys (1993-10-26-2000-02-21), plk. Algis Vaičeliūnas (2000-02-22-2003-09-17), plk. Algimantas Vyšniauskas (laikinai ejo pareigas) (2003-09-18-2005-07-31), plk. Arūnas Balčiūnas (2005-08-01-2008-08-31), brg. gen. Edvardas Mažeikis (2008-09-01-2010-05-09), plk. Gintaras Bagdonas (2010-05-10-2012-06-05), plk. Eugenijus Vosylius (2012-06-06-2015-07-01), plk. Raimundas Matulis (2015-08-03-dabar).

Nuo 1994 m. iki 2015 m. Akademija išleido 22 absolventų laidas. Per tą 
patị laikotarpi Lietuvos karo akademijoje buvo parengti 2394 absolventai: iš jų nuolatines bakalauro studijas baige 1641 kariūnas; nuolatines magistrantūros studijas - 56 absolventai; ištęstines magistrantūros studijas - 147 absolventai (vadybos ir verslo administravimo diplomai ịteikti 44 absolventams; žmonių išteklių vadybos magistro diplomai - 46; visuomenès saugumo magistro diplomai - 10; politikos mokslų magistro diplomai - 47 klausytojams); ištęstines bakalauro studijas baigè 550 klausytojų (LKA Studijų skyriaus duomenys).

Per 1994-2015 m. laikotarpi, pradžioje (iki 1996 m.) Lietuvos Respublikos Ministro Pirmininko potvarkiais, vèliau (nuo 1997 m.) Lietuvos Respublikos Prezidento dekretais buvo suteiktas pirmasis karininko - leitenanto - laipsnis 1468 Lietuvos karo akademijos absolventams ir 42 Akademijos absolventams, baigusiems užsienio karo akademijas ir kitas karines mokymo įstaigas (LR Ministrų Pirmininkų A. Šleževičiaus, M. Stankevičiaus potvarkiai: Žin., 1994, Nr. 455; 1995, Nr. 345; 1996, Nr. 242. LR Prezidentu A. Brazausko, R. Pakso, V. Adamkaus, D. Grybauskaitès, 1. e. Prezidento pareigas A. Paulausko dekretai: Žin., 1997, Nr. 1355; 1999, Nr. 489; 2000, Nr. 898; 2001, Nr. 1383, 2002, Nr. 1796; 2003, Nr. 150; 2004, Nr. 136; 2005, Nr. 354; 2006, Nr. 665; 2007, Nr. 1K-1032, 2008, Nr. 1K-1419; 2009, Nr. 1K-1916; 2010, Nr. 1K-399; 2011, 1K-760; 2012, Nr. 1K-1147; 2013, Nr. 1K-1529; 2014, Nr. 1K-20; 2015, Nr. 1K-408 (LKA Studijų skyriaus duomenys)).

Lietuvos Respublikos Ministro Pirmininko potvarkiais, Lietuvos Respublikos Prezidento dekretais taip pat buvo suteikiamas pirmasis karininko laipsnis krašto apsaugos sistemoje tarnaujantiems kariams, civiliams tarnautojams, baigusiems karinio mokymo ịstaigas ar turintiems aukštajj̨ išsilavinimą ir baigusiems karininkų kursus Lietuvos karo akademijoje ir kitur.

Tolesniam karininkų rengimui ir jų kvalifikacijos kèlimui Lietuvos karo akademijoje buvo steigiami ịvairūs specializuoti ilgalaikiai ir trumpalaikiai, nuolatiniai ir laikini kursai. Nuo 2003 m. iki 2015 m. ịvairius 27 Lietuvos karo akademijos kursus baigè 2562 klausytojai (LKA Studijų skyriaus duomenys).

Nuo $2004 \mathrm{~m}$. Lietuvos karo akademijoje organizuojamas užsienio valstybių karininkų mokymas. Nuo 2004 m. iki 2015 m. 378 klausytojai iš 18 užsienio valstybių sėkmingai Akademijoje baigè ịvairius kursus.

Vien 2015 m. Lietuvos karo akademijoje vyko 10 kursų: tarptautinès politikos ir diplomatijos kursus baigė 10, kuopų vadų kursus - 41, jaunesniujų štabo karininkų kursus - 46, jaunesniujų karininkų vadų mokymus (JKVM, 3 m.) - 52, Vytauto Didžiojo karininkų kursus - 43, oro pajègų vyresniujų štabo karininkų kursus (nuo $2007 \mathrm{~m}$.) - 10, oro pajègų štabo karininkų kursus - 21, Nacionalinio saugumo kursus - 44, valstybės tarnautojų karybos pagrindų kursus (nacionaliniai būtinujjų karinių žinių igijimo kursai) - 34, karininkų specialistų pagrindinio karinio parengimo kursus -25 klausytojai, kuriuose dèsto Lietuvos karo akademijos, kariuomenès instruktoriai, lektoriai, taip pat NATO valstybių kariai bei civiliai (žr. 1 lentelę). 


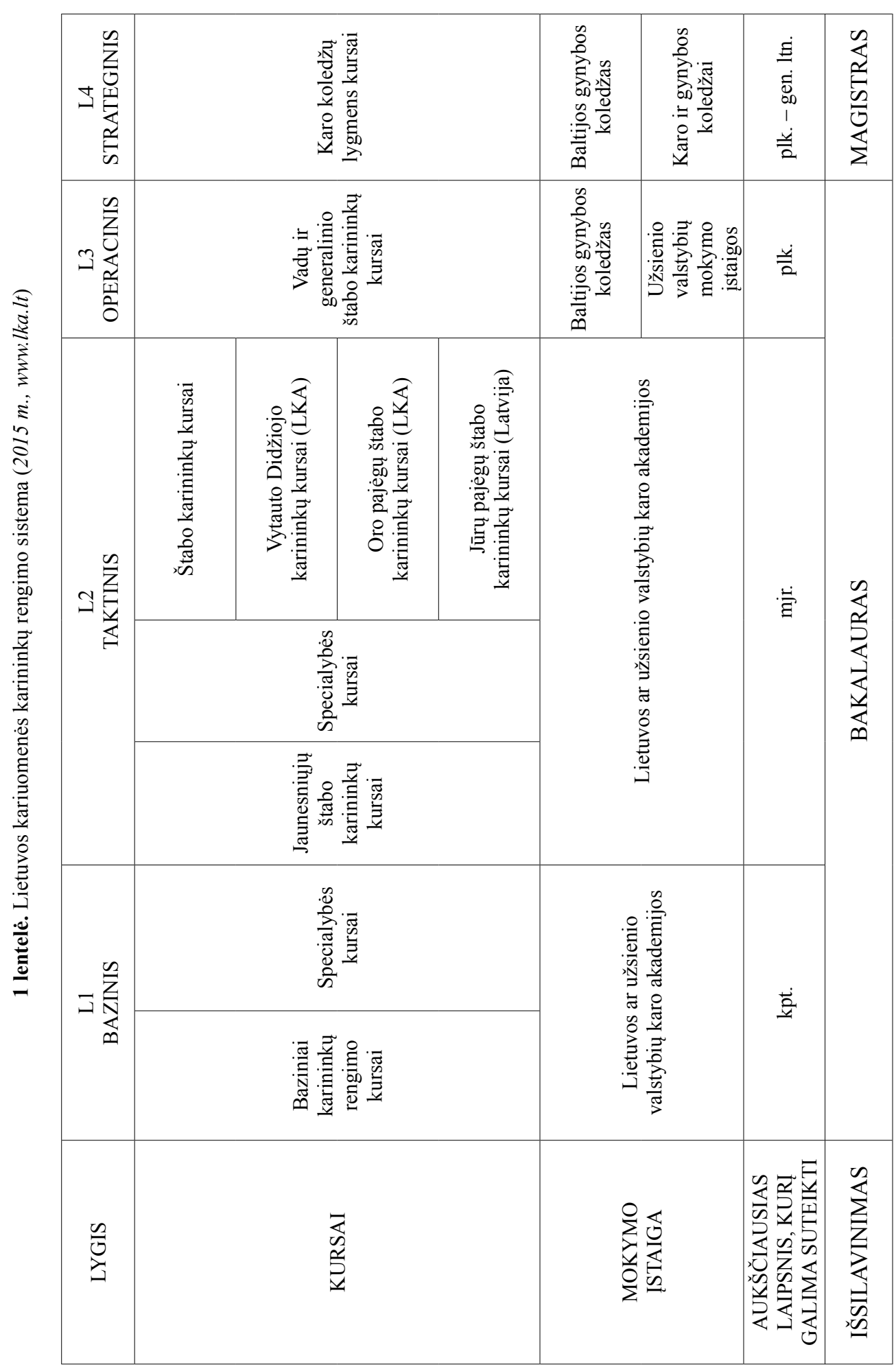


Platus ir turiningas Lietuvos karo akademijos bendradarbiavimas vyksta su Lietuvos universitetais ir kt. institucijomis, plètojami intensyvūs tarptautiniai ryšiai.

Lietuvos karo akademija pasirašiusi bendradarbiavimo sutartis su Lietuvos aukštosiomis mokyklomis, istorijos ir karo muziejais, ugdymo įstaigomis, valstybinèmis institucijomis, nevyriausybinèmis organizacijomis. Šio bendradarbiavimo esmè - apsikeisti moksline ir metodine patirtimi, organizuoti karininkų rengimą, bendrus kultūros ir sporto renginius.

Akademinis bendradarbiavimas su kitų šalių aukštojo mokslo institucijomis (Jungtinių Amerikos Valstijų, Didžiosios Britanijos, Vokietijos, Prancūzijos, Austrijos, Skandinavijos šalių, Čekijos, Lenkijos, Estijos, Latvijos ir kitomis) plètojamas ir mokslo, ir studijų kryptimis: vykdomi bendri tarptautiniai moksliniai tyrimai, dẻstytojų ir studentų mainų programa, rengiamos mokslinès ir metodinès konferencijos, leidžiami bendri moksliniai leidiniai ir kt. Lietuvos karo akademijos mokslo darbuotojai ir desstytojai aktyviai dalyvauja tarptautinių mokslo draugijų ir asociacijų veikloje. Kartu su užsienio partneriais įgyvendinami bendri kultūriniai ir edukaciniai projektai.

Nuo $2005 \mathrm{~m}$. Generolo Jono Žemaičio Lietuvos karo akademija dalyvauja Erasmus (nuo 2014 m. - Erasmus + ) tarptautinèje studijų mainų programoje: 2005-2007 m. dalyvavo „Socrates“ veikloje, o nuo 2007 m. - Mokymosi visą gyvenimą programoje. Dalyvavimas šioje programoje yra tiesiogiai susijęs su Bolonijos proceso tikslų ir uždavinių igyvendinimu karinèje aukštojo mokslo institucijoje, su dèstytojų ir administracijos darbuotojų aktyvumo skatinimu ir studijų kokybės gerinimu.

Europos Sajungos šaliu karo akademijų bendradarbiavimas suaktyvejo 2008 m., Prancūzijai iškèlus iniciatyvą sukurti karinę Erasmus studijų mainų programą, kurios tikslas - kariūnų ir jaunesniųų karininkų mainai tarp ES karo mokyklų.

Lietuvos karo akademija šiuo metu yra pasirašiusi 6 Erasmus dvišalio bendradarbiavimo sutartis su:

- Varšuvos universiteto Istorijos fakultetu, Lenkija (PL WARSZAWA 01);

- Varšuvos Nacionaliniu gynybos universitetu, Lenkija (PL WARSZAWA 68);

- Generolo Tado Kosciuškos sausumos pajėgų aukštaja karininkų mokykla, Lenkija (PL WROCLAW 25);

- Brno Gynybos universitetu, Čekijos Respublika (CZ BRNO 10);

- Teresès karo akademija, Austrija (A WIENER 04);

- Estijos aviacijos akademija (EE TARTU 03).

Dalyvavimas Erasmus studijų mainų programos veikloje Lietuvos karo akademijai padeda tobulinti mokymo ir auklejjimo procesą ir užtikrinti studijų kokybę institucijoje, skatina tarptautinị bendradarbiavimą ir mokslinès bei pedagoginès veiklos pažangą.

Studijų kokybès vertinimo centras $2014 \mathrm{~m}$. rugsèjo $15 \mathrm{~d}$. akreditavo Generolo Jono Žemaičio Lietuvos karo akademiją 6 metams. Tai yra didžiausias įverti- 
nimas, kokị gali skirti vertintojai institucijai. Vertinimo grupès parengtoje išvadoje grupès nariai pažymėjo Akademijos veiklos stipriąsias puses, gerają patirtị, nurodė tobulintinus dalykus ir pateikè rekomendacijų, kaip pagerinti situaciją.

\section{Atsargos karininkų rengimas}

Atsargos karininkai pagal Lietuvos Respublikos Seimo priimtą „Lietuvos Respublikos karo prievolès istatyma“" (Žin., 1996, Nr. I-1593) rengiami nuo 1996 m., o Lietuvos karo akademijoje nuo 1998 m.

Pašaukti i jaunesniųų karininkų vadų mokymus (toliau - JKVM) karo prievolininkai Krašto apsaugos savanorių pajègų vado įsakymu skiriami ị karinio mokymo padaliniuose organizuojamus JKVM kursus.

Tokie kursai aukštujų mokyklų studentams buvo rengiami Lietuvos didžiojo kunigaikščio Butigeidžio dragūnų batalione Klaipedoje, Krašto apsaugos savanoriu pajègų Prisikèlimo apygardos 6-ojoje rinktinèje Šiauliuose, Generolo Jono Žemaičio Lietuvos karo akademijoje Vilniuje ir Divizijos generolo Stasio Raštikio puskarininkių mokykloje Kaune.

JKVM dalyvaujantys karo prievolininkai (toliau - klausytojai) JKVM kursų metu Krašto apsaugos sistemos organizavimo ir karo tarnybos įstatymo (Žin., 1998, Nr. 49-1325) nustatyta tvarka aprūpinami apranga, maistu, jiems mokomos privalomosios pradinės karo tarnybos kariams nustatytos išmokos buitinėms išlaidoms ir premijos, taikomos socialinès garantijos. Už drausmès pažeidimus, padarytus JKVM kursų metu, klausytojas drausminèn atsakomybėn traukiamas Lietuvos Respublikos kariuomenès drausmès statuto nustatyta tvarka.

$2001 \mathrm{~m}$. liepą Lietuvos kariuomenès vadų kursus baigè pirmoji apie 150 aukštujų mokyklų studentų laida. Trejus metus vaikinai mokèsi karo meno teorijos, dalyvavo mokymuose ịvairiuose poligonuose, buvo ugdomi kaip būrio vadai. Studentams, sėkmingai atlikusiems praktiką ir išlaikiusiems kvalifikacinị egzaminą, suteiktas atsargos leitenanto laipsnis. Dalis jų nusprende pasilikti tarnauti ir netrukus buvo paskirti $i$ karinius dalinius.

2006 m. dèl kariuomenès reorganizavimo Lietuvos kariuomenès vado įsakymu studentų rengimas buvo sustabdytas, išskyrus Klaipėdą, kur Karinių jūrų pajègų mokymo centras organizuoja karinių jūrų pajègų jaunesniųjų karininkų vadų mokymus Klaipedos universiteto Jūreivystės instituto ir Lietuvos aukštosios jūreivystès mokyklos studentams, o $2012 \mathrm{~m}$. - atnaujintas, siekiant stiprinti šalies gynybinius pajègumus - rengti karininkus (būrių vadus) Lietuvos kariuomenès rezervui, jai reikalingus specialistus, ugdyti Lietuvos Respublikos pilietị, pasirengusị atlikti konstitucinę pareigą - ginklu ginti savo valstybę.

2012 m. rugsèjo 8 d., Kaune (Divizijos generolo Stasio Raštikio Lietuvos kariuomenès mokykloje), Klaipėdoje (Lietuvos didžiojo kunigaikščio Butigeidžio dragūnų batalione) ir Vilniuje (Generolo Jono Žemaičio Lietuvos karo akademijoje) prasidejo JKVM, kuriuose per du šimtus aukštujų mokyklų studentų mokèsi 
karybos ir siekė atsargos karininko laipsnio. Atsargos karininkų mokymai pagal pėstininkų programas buvo atnaujinti po šešerių metų pertraukos.

Sprendimas atnaujinti karinius mokymus studentams priimtas siekiant stiprinti šalies gynybinius pajëgumus - kariuomenès rezervą. Krašto apsaugos ministerija jau kelinti metai nuosekliai sprendžia kariuomenès rezervo papildymo ir rengimo problemą, susidariusią $2008 \mathrm{~m}$. sustabdžius šaukimą ị privalomają pradinę karo tarnybą. Tokie mokymai taip pat leis kariuomenei atsirinkti ir savo gretas, kai atsiras poreikis, papildyti reikalingais tam tikrų sričių specialistais.

Mokymai trunka trejus metus. Aukštụjų mokyklų studentai kartą per savaitę mokosi karybos teorijos, kurią taip pat taiko ir lauko pratybose, kurios vyksta vidutiniškai dvi savaites ir trunka vasaros atostogų metu.

Vien Akademijoje 2012-2015 m. I laidą (po pertraukos) baigè 52 klausytojai, iš jų 44 suteiktas jaunesniujų vadų atsargos karininkų laipsnis (8 neturejo aukštojo išsilavinimo).

2015 m. karinių žinių buvo nusprendęs ịgyti 181 studentas, dalyvausiantis Lietuvos karo akademijos organizuojamuose mokymuose: Lietuvos karo akademijoje -77 , Dragūnų batalione - 24, Lietuvos kariuomenès mokykloje - 80 studentų.

Pagal tarpukario Lietuvos tradicijas atsargos karininkų kursų klausytojai vadinami kariūnais aspirantais, jie ịgyja bazinių karinių žinių ir ịgūdžių, rengiasi veikti kariniame vienete ir jam vadovauti.

Atsargos karininkai turi realias galimybes tarnauti Lietuvos kariuomeneje ir siekti karininko karjeros.

Aukštujų mokyklų studentai ir absolventai, norintys atlikti privalomają pradinę karo tarnybą nenuolatiniu būdu, kviečiami registruotis ị Jaunesniujų karininkų vadų mokymus. $2016 \mathrm{~m}$. jaunuoliai gali pasirinkti iš trijų skirtingų mokymų programų - Pèstininko būrio vado, Karo medicinos gydytojo ir Laivo kovinès dalies vado.

Dalyvauti trejus metus po du savaitgalius per ménesį trunkančiuose jaunesniujjų karininkų vadų mokymuose kviečiami 18 iki 32 metų aukštųjų mokyklų studentai ir absolventai. Registracija ị šiuos mokymus prasidejo $2016 \mathrm{~m}$. sausio 4 d. ir vyks iki $2016 \mathrm{~m}$. rugsèjo 30 dienos.

I pėstininkų būrio vado kursus $2016 \mathrm{~m}$. planuojama priimti 150 jaunuolių, i karo medicinos gydytojo ir laivo kovinès dalies vado - po 20 jaunuolių.

Pèstininkų būrio vado kursai organizuojami trijuose miestuose - Vilniuje, Kaune, Klaipèdoje; karo medicinos gydytojo - Kaune; laivo kovinès dalies vado Klaipedoje. Vilniuje jaunuoliai mokysis Generolo Jono Žemaičio Lietuvos karo akademijoje, Klaipėdoje - Lietuvos didžiojo kunigaikščio Butigeidžio dragūnų motorizuotajame pėstininkų batalione, Kaune - Divizijos generolo Stasio Raštikio Lietuvos kariuomenès mokykloje.

Per jaunesniujų karininkų vadų mokymus jaunuoliai dalyvauja paskaitose ir igyja ryšių, topografijos, taktikos, medicinos, kitų reikalingų žinių. Taip pat ugdomos kursantų lyderio savybès, gebejjimas dirbti kolektyve. Galutinis kursų vertinimas susideda iš dviejų savaičių trukmès lauko taktinių pratybų, kai vertinami prak- 
tiniai dalyvių kariniai bei vadovavimo ịn̄̄žiai. Baigusiems kursą suteikiamas atsargos leitenanto laipsnis, jie yra įrašomi ị Lietuvos kariuomenès personalo rezervą.

Jaunesniųjų karininkų vadų mokymai - privalomoji pradinè karo tarnyba, kurią atlikdami aukštujų mokyklų studentai ir absolventai igyja pagrindinį karini parengtumą, pasirengia veikti karinio vieneto sudettyje ir jam vadovauti (Krašto apsauga, 2015, Nr. 11 (298): 19; Krašto apsauga, 2016, Nr. 1 (306): 11).

\section{Kiti karininkų rengimo ir kvalifikacijos kèlimo būdai}

Lietuvos kariuomenès Generolo Adolfo Ramanausko kovinio rengimo centras. $1991 \mathrm{~m}$. lapkričio $23 \mathrm{~d}$. Krašto apsaugos departamento direktoriaus A. Butkevičiaus įsakymu Nemenčinėje įkurtas KAD Civilinès saugos tarnybos mokymo centras. Pagrindinis uždavinys - mokyti civilinès saugos specialistus.

1995 m. spalio 1 d. Centras tapo atskiru krašto apsaugos sistemos specialistų kvalifikacijos kèlimo ir tobulinimosi centru.

$1998 \mathrm{~m}$. vasario $2 \mathrm{~d}$. Krašto apsaugos ministro įsakymu Centro pavadinimas keičiamas į Karių profesinio tobulinimo centrą (KPTC), kurio funkcijos rūpintis karininkų ir puskarininkių kvalifikacijos kèlimu. Pagrindinis uždavinys - mokyti civilinès saugos specialistus.

Pagrindine KPTC veiklos kryptis - mokyti karius, tobulinti KAS ir kitu institucijų valstybès tarnautojų profesinius įgūdžius. Čia nuolat rengiami įvairūs kvalifikacijos kẻlimo kursai, konferencijos, seminarai, ir kiti renginiai Lietuvos kariuomenès karininkams, puskapininkiams, seržantams; igyvendinamos Baltijos regiono šalių karių mokymo programos. Klausytojai testuojami, gauna kursų baigimo pažymèjimus.

Danijos, Didžiosios Britanijos, JAV Švedijos, Vokietijos ir kitų Vakarų šalių vyriausybès, ginkluotosios pajègos ir tarptautinès organizacijos padejo aprūpinti KPTC mokymo bazę šiuolaikine kompiuterine technika ir mokymo priemonemis, užsienio instruktoriai moko ir konsultuoja Centro dèstytojus (Krašto apsauga, 2001, Nr. (1) 1:14).

1998 m. vasario 9 d. Centrui suteikiamas žymaus Lietuvos pokario rezistencinès kovos vado gen. Adolfo Ramanausko vardas ir patvirtinamas Centro, kaip karinès mokymo įstaigos, ženklas.

2003 m. gegužès 29 d. krašto apsaugos ministro ịsakymu Centro pavadinimas keičiamas ị Generolo Adolfo Ramanausko kovinio rengimo centrą. Patvirtinamas naujas Centro ženklas. Iš esmès keičiasi Centro užduotys ir funkcijos.

Kokie Centro pagrindinès veiklos aspektai? Centras įsipareigojo organizuoti ir vykdyti karių kovinį rengimą, atitinkantį Lietuvos kariuomenès ir NATO keliamus reikalavimus.

Centre yra sudarytos sąlygos Lietuvos kariuomenès vienetams vykdyti įvairių lygmenų štabų mokymus naudojant kompiuterinę operacijų imitavimo sistemą JCATS (Joint Conflict and Tactical Simulation), čia sėkmingai organizuojami štabo 
karininkų ir specialistų trumpalaikiai kovinio rengimo ir pasirengimo taikos remimo operacijoms kursai, seminarai, pratybos bei kiti šalies ir tarptautiniai mokymo renginiai. Čia vykdomi ir KAS karių ir civilių aplinkos apsaugos mokymai.

Reikia pažymèti, kad Centras per visus veiklos metus nuveikè nemažai. Jis kūrèsi, tobulèjo, plètojo mokymo bazę, infrastruktūrą. Nesvarbu, kad ne kartą keitėsi Centro užduotys ir prioritetai. Taigi Lietuvos kariuomenès sistemoje veikia modernus, NATO standartus atitinkantis mokymo centras, turintis puikias auditorijas, kompiuterinę taktikos imitavimo sistemą, valgyklą, viešbutị, sporto ir poilsio bazę. $2006 \mathrm{~m}$. rugsèjo $7 \mathrm{~d}$. iškilmingai atidarytas Taktikos imitavimo centras JCATS leido ị visiškai naują lygị pakelti karinių vienetų ir štabų rengimą. Dabar Lietuvos kariniai vienetai jau neįsivaizduoja štabų rengimo be šios sistemos.

$2007 \mathrm{~m}$. sausio $16 \mathrm{~d}$. Kovinio rengimo centrui krašto apsaugos ministras Juozas Olekas iškilmingai įteikè karinio vieneto simbolį - kovos vèliavą.

Atsižvelgiant ị Lietuvos kariuomenès transformacijos plano gaires, Generolo Adolfo Ramanausko kovinio rengimo centrui buvo keliami nauji reikalavimai.

„<...> Reformuoti Kovinio rengimo centra $i$ Kolektyvinio (jungtinio) rengimo centrą. Šio centro uždavinys - vykdyti kariuomenes vienetu kovinio parengimo bei kovinès parengties vertinima ir teikti pasiūlymus dèl kovinio rengimo tobulinimo. Tikslinga sujungti Kovinio rengimo centra ir Kariuomenes centrini poligona $i$ viena struktūrini padalinị ir šiuo metu Kovinio rengimo centre organizuojamu individualaus rengimo kursu vykdyma perduoti kitoms mokymo institucijoms - Generolo Jono Žemaičio Lietuvos karo akademijai ir Divizijos generolo Stasio Raštikio puskarininkiu mokyklai. Šis struktūrinis padalinys turi sudaryti sqlygas vykdyti bataliono grupés dydžio vieneto jungtinius mokymus. Parengti kolektyvinio rengimo standartus $<\ldots>$. " (Citata iš Lietuvos kariuomenès transformacijos plano gairių, 2008).

Centras kovinio rengimo ir aplinkos apsaugos mokymo srityje vykdo ir ịvairius tarptautinius projektus. Vyksta bendradarbiavimas su analogiškais kitų šaliu mokymo centrais. Stengiamasi praktiniame darbe perimti jų patirti. Palaikomi ryšiai su Danija, Estija, Ukraina, Gruzija, Rumunija.

Lietuvos kariuomenès Sausumos pajègu Juozo Lukšos mokymo centras. $2011 \mathrm{~m}$. rugpjūčio 10 d. Rukloje (Jonavos r.) vyko oficiali Lietuvos kariuomenès Sausumos pajègų Juozo Lukšos mokymo centro įsteigimo ir vardo suteikimo ceremonija. Centro tikslas - rengti Lietuvos kariuomenès Sausumos pajejgoms reikalingus specialistus ir vadus. Pagrindiniai Sausumos pajègų Juozo Lukšos mokymo centro uždaviniai: organizuoti ir vykdyti Sausumos pajègų karių karinį mokymą, karinių vienetų kovinį rengimą ir užtikrinti karinę ekspertizę manevro, karo inžinerijos, žvalgybos ir paramos ugnimi srityse (Krašto apsauga, 2011, Nr. 16, (2012): 2).

Kursai parengti būsimiems štabų inžinerijos karininkams, jų asistentams ar kovinès inžinerinès paramos vienetų vadams, planuojantiems inžinerinę taktiką, organizuojantiems ir taikantiems praktikoje. Kursas suskirstytas ị 4 mokymo dalis (inžinerinè doktrina, gynybinių operacijų inžinerinès paramos planavimas, puolamụjų operacijų inžinerinès paramos planavimas, stabilumo operacijų inžinerinès 
paramos planavimas).

Mokymo centre Karo inžinerijos kursų ekspertai ir instruktoriai nuolat analizuoja gautą naujausią informaciją, NATO, Lietuvos kariuomenès standartus, kitą NATO partnerių mokomają ir techninę medžiagą, kurią pratybų metu perteikia ị kursus atvykusiems klausytojams.

Kurso klausytojai iš Juozo Vitkaus inžinerijos bataliono igytas žinias gali panaudoti jau $2016 \mathrm{~m}$. rengiant pirmuosius privalomosios pradinès karo tarnybos karius.

Dr. Basanavičius karo medicinos tarnybos mokymo centras. $1991 \mathrm{~m}$. vasario 22 d. atkurta Lietuvos kariuomenès Karo medicinos tarnyba Kaune plète savo veiklą užtikrindama karių asmens ir visuomenès sveikatos priežiūrą bei medicininę ekspertizę, nacionalinių sveikatos priežiūros programų ịgyvendinimą, pajègų ir jų padalinių karinių ir kitų operacijų medicininę paramą pagal NATO standartus Lietuvoje ir už jos ribų, organizuodama karo medikų mokymą ir kvalifikacijos kèlimą, steigdama bendrus su civilinèmis sveikatos priežiūros ịstaigomis pirminès sveikatos priežiūros centrus.

2007 m. rugpjūčio 2 d. aštuoniolikai Kauno medicinos universiteto absolventų buvo ịteikti atsargos karininko - leitenanto - laipsniai. Tai buvo jau šeštoji Kauno medicinos universiteto absolventų laida, sékmingai baigusi vadų kursus Karo medicinos tarnybos mokymo centre.

$2007 \mathrm{~m}$. rugsèjo 23 - spalio $5 \mathrm{~d}$. Karo medicinos tarnyboje vyko tarptautiniai baziniai štabo medicinos karininkų kursai. Lietuvos karo medicinos tarnybos Karo medicinos mokymo centras, padedant Estijos, Latvijos ir Švedijos karo medicinos mokymo centrų instruktoriams, jau trečius metus iš eilès organizuoja dviejų savaičių trukmès kursus Estijos, Latvijos, Lietuvos, Švedijos, taip pat Armėnijos, Gruzijos ir Ukrainos karo medikams. Tarptautinių bazinių štabo medicinos karininkų kursų metu karo medicinos gydytojai buvo paruošiami dirbti bataliono lygmens štabe kaip medicinos karininkai bataliono štabui planuojant, organizuojant ir vykdant įvairias karines operacijas.

Pvz., 2002-2007 m. Karo medicinos tarnyba parengè 80 atsargos karininkųmedicinos būrių vadų. Atsargos karininkai yra ịtraukiami ị Krašto apsaugos savanorių pajėgų (KASP) rezervą ir šaukiami dalyvauti ịvairiuose mokymuose.

Nemažai KASP karių vyksta dalyvauti ị tarptautines misijas. Pvz., 2007 m. Afganistano Goro provincijos atstatymo grupès Medicinos skyriaus sudètyje tarnavo ir trys KASP kariai - vienas karo medicinos gydytojas ir dvi karo medicinos gydytojo padejjejjos. $2008 \mathrm{~m}$. lapkričio $12 \mathrm{~d}$. krašto apsaugos ministro ịsakymu Karo medicinos tarnybai suteiktas Dr. Jono Basanavičiaus vardas.

Dr. Jono Basanavičiaus karo medicinos tarnyboje vyksta tarptautiniai baziniai štabo medicinos karininkų kursai. Antai 2010 m. rugsẻjo 21-29 d. tokius mokymus Karo medicinos mokymo centras organizavo jau ketvirtą kartą. Dvylikai karo medicinos gydytojų iš Armènijos, Estijos, Gruzijos ir Lietuvos paskaitas skaitė ne tik patyrę Dr. Jono Basanavičiaus karo medicinos tarnybos karininkai, bet ir ins- 
truktoriai iš Generolo Jono Žemaičio Lietuvos karo akademijos, Lietuvos didžiojo kunigaikščio Vytenio bendrosios paramos logistikos bataliono, karo medicinos specialistai iš Estijos ir Latvijos.

2012 m. buvo vykdoma Lietuvos kariuomenès Dr. Jono Basanavičiaus karo medicinos tarnybos reforma, kurios esmè - perorientuoti karo medicinos tarnybos veiklą, stiprinant karinès medicininès paramos vienetus, kurie yra neatsiejama šalies gynybinių pajègumų dalis. Kartu siekiama atsisakyti didžiosios dalies iki šiol Karo medicinos tarnybos teiktų pirminès sveikatos priežiūros paslaugų, perduodant šias funkcijas civilinėms sveikatos priežiūros ịstaigoms.

Nuo 2013 m. sausio 3 d. prasidèjo registracija ị jaunesniųjų karininkų vadų mokymus, skirtus medicinos studentams. Lietuvos aukštujų mokyklų medicinos ar odontologijos mokslų studentai turejjo galimybę tapti karo medikais.

Jaunesniujų karininkų vadų mokymuose studentams buvo suteikiama galimybė igyti atsargos karininko laipsnị ir karo medicinos gydytojo kvalifikaciją. Baigusieji studijas gali rinktis karo mediko kelią. Jei baigęs studijas asmuo nuspręs karjeros siekti civiliniame gyvenime ir likti atsargos karininku, galès būti kviečiamas prisijungti prie savo kolegų kariuomenejje ir, pavyzdžiui, išvykti ị tarptautinę misiją, kurioje igytų neįkainojamos patirties.

Jaunesniųjų karininkų vadų mokymai medicinos studentams trunka trejus mokslo metus. Pirmais mokymų metais studentai iggya bazinių karinių žinių ir ịgūdžių, antraisiais - mokosi vadovauti medicinos paramos vienetui, o trečiaisiais - atlieka karo medicinos gydytojo funkcijas. Šie mokymai vyksta pagal specialiai karo medicinos gydytojams rengti pritaikytą programą.

Pvz., 2013 m. balandžio 20-21 d. Dr. Jono Basanavičiaus karo medicinos tarnyboje vyko pratybos rezervo kariams. Šiomis dienomis ị karinę tarnybą buvo pakviesti medikai, tarnaujantys Krašto apsaugos savanorių pajègose. Pratybose dalyvavo 12 karių. Gydytojai, gydytojų padejejjai ir paramedikai, dirbantys respublikiniuose pirminès asmens sveikatos priežiūros centruose, pratybose dalyvavo jau nebe pirmą kartą.

Per metus jie keliolika kartų tampa karo gydytojais, karo gydytojų padejejjais, karo paramedikais. Pratybų metu vyksta teoriniai ir praktiniai užsiemmimai, didžiausias dèmesys skiriamas kariniam individuliam ir kolektyviniam rengimui. Vykstant tarptautinėms ir kitoms pratyboms kartu su Karo medicinos tarnybos medikais kaip lygiaverčiai komandos nariai sėkmingai pratybose dalyvauja ir rezervo karo medikai.

Ši kartą rezervistai buvo supažindinti su aviacinès medicinos ir aeromedicininès evakuacijos pagrindais. Penki gydytojai susipažino su kovinių operacijų medicininès paramos plano rengimo principais. Be abejo, ir patiems gydytojams vèliau teko parengti medicininès paramos planą pateiktai kovinei operacijai - šiuo atveju priešui stabdyti. Lygiagrečiai tuo pačiu metu karo gydytojo padejjejai ir paramedikai tobulino praktinius ịgūdžius, kurie būtini teikiant neatidèliotiną pagalbą nukentejusiesiems.

2013 m. rugsèjo 7 d. apie 20 mediciną aukštosiose mokyklose studijuojan- 
čių jaunuolių Divizijos generolo Stasio Raštikio Lietuvos kariuomenès mokykloje Kaune pradejjo jaunesniujų karininkų vadų mokymus, kuriuos baigę igijo karo mediko kvalifikaciją, jiems buvo suteiktas atsargos karininko laipsnis.

Dr. Jono Basanavičiaus karo medicinos tarnyba yra vienas iš Lietuvos kariuomenès Logistikos valdybos padalinių, užtikrinančių medicininę paramą Lietuvos kariuomenès vienetams operacijų metu Lietuvoje ir už jos ribų, vykdančių karių sveikatos priežiūrą ir aprūpinančių medicinos priemonèmis, taip pat rengiančių karo medicinos personalą, organizuojančių medicininị švietimą ir mokymą (Krašto apsauga, 2015, Nr. 8 (295): 11).

Lietuvos kariuomenès karininkų studijos užsienyje. Tik ką atkūrus Lietuvos kariuomenę buvo susirūpinta jos karininkų mokymu užsienyje ir kvalifikacijos tobulinimu. 1992 m. pirmieji Lietuvos karininkai išvyko ị ilgalaikius karinius kursus Vakarų valstybėse. Lietuvos karininkai gali pasigirti moksliniais pasiekimais, prestižinių aukštojo mokslo įstaigų Lietuvoje ir užsienio šalyse išduotais diplomais, dalis jų yra ịgiję po keletą specialybių. Lietuvos karininkai nuolat tobulina savo žinias JAV karo mokyklose pagal dvišalę karinio bendradarbiavimo sutartị.

Jau ne vienus metus palaikomi draugiški ryšiai su Jungtinių Valstijų, Didžiosios Britanijos, Vokietijos, Prancūzijos, Austrijos, Skandinavijos šalių, Čekijos, Lenkijos, Estijos ir Latvijos karo mokyklomis.

Lietuvos krašto apsaugos sistemos karininkai dalyvavo ìvairiuose kvalifikacijos kèlimo kursuose: NATO gynybos koledže Romoje mokosi NATO šaliu karininkai, turintys ne žemesnị kaip pulkininko leitenanto laipsnị. Nuo 1993 m. ị koledžą kviečiami ir karininkai iš Vidurio bei Rytų Europos. Kartu su NATO šalių atstovais mokèsi karininkai iš Rusijos, Ukrainos ir Bulgarijos.

Lietuvos kariuomenèje nuo pat valstybès atkūrimo pradžios daug dėmesio buvo skiriama karininkų kvalifikacijos tobulinimui. NATO šalių karo mokyklose ir akademijose pagal šios sajungos standartus iki 1997 m. pradžios mokèsi 303 krašto apsaugos sistemos darbuotojai. 1997 m. užsienyje karo mokslus studijavo 86 karininkai. Daugiausia jų parenge ir rengia Vokietija (nuo 1992 m. iki 1997 m. - 79, 1997 m. - 37), JAV (atitinkamai 53 ir 23), Danija (51 ir 5), Kanada (34 ir 2).

$2000 \mathrm{~m}$. gegužès $31 \mathrm{~d}$. JAV karinių oro pajègų akademijos (Kolorado valstija, Kolorado Springsas) baigimo diplomus ir Lietuvos kariuomenès leitenanto laipsni gavo du lietuviai - Mindaugas Butkus ir Aidas Kerutis.

Studijavę ketverius metus, jie mokslus baigé labai gerai. JAV karinių oro pajëgų departamento Tarptautinių programų tarybos pirmininkas Raymond E. Franck Lietuvos kariuomenès vadui brg. gen. Jonui Kronkaičiui atsiuntė laišką, kuriame rašo, kad abu lietuviai studijavo pavyzdingai, jiems sekèsi ir karinès, ir akademinès disciplinos. Iš 945 kadetų Mindaugas Butkus ir Aidas Kerutis pateko tarp 30 proc. geriausiai besimokiusių absolventų.

I šias studijas savo jaunuolius buvo delegavusios 10 valstybių. Teisę mokytis JAV karinių oro pajègų akademijoje laimi tik geriausieji. Lietuva buvo vienintele užsienio valstybè, iš kurios ị šią akademiją pateko net du vaikinai. 
1998 spalio 22 d. atkurtai Lietuvos karo policijai teko formuoti tokią struktūrą, kokios dar nebuvo Lietuvos kariuomenès istorijoje. Pradžia visada nelengva trūko specialistų, specialiosios literatūros, beje, jos ir dabar trūksta. Patirties jauni specialistai sėmèsi užsienio valstybèse.

Lietuvai labai svarbi ekonomiškai stiprių šalių pagalba, nes jos apmokejo 98 proc. išlaidų. Antai nuo 1992 m. iki 2001 m. 1080 Lietuvos karininkų buvo baigusių mokyklas JAV, Vokietijoje, Prancūzijoje, Didžiojoje Britanijoje, Švedijoje, Norvegijoje, Čekijoje, Lenkijoje ir kitose Vakarų šalyse.

Nuo $2005 \mathrm{~m}$. Lietuvos karininkai dalyvauja nacionaliniame generalinio štabo / admiraliteto kurse (LGAN - vok. Nationaler Lehrgang Generalstabs-/Admiralstabsdienst), kuris skirtas tik NATO ir ES šalims. $2005 \mathrm{~m}$. paskutini tarptautini generalinio štabo / admiraliteto kursą (LGAr - vok. Lehrgang Generalstabs-/Admiralstabsdienst mit internationaler Beteiligung) ir EURO kursą baigia trys Lietuvos karininkai.

Bundesvero vadų akademija. Vokietijos bundesvero Generalinio štabo akademija (toliau Generalinio štabo akademija) yra aukščiausia karinių pajègų mokymo institucija, ikurta $1957 \mathrm{~m}$. Generalinio štabo akademija $1958 \mathrm{~m}$. buvo perkelta iš Bado miesto ị Hamburgą - antrą didžiausią po Berlyno miestą Vokietijoje.

Pagrindinè akademijos užduotis - rengti karininkus darbui ịvairaus lygmens štabuose. Visų trijų kariuomenès rūšių (sausumos, karo aviacijos ir karo laivyno) karininkai paprastai rengiami kartu. Beveik pusę mokymosi laiko jie praleidžia kartu auditorijose, įvairiose pratybose ir išvykose ị karinius dalinius. Akademijoje nuolat studijuoja apie 600 karininkų, tarp jų apie 100 užsieniečių iš 50 pasaulio šalių. Per metus akademija paruošia daugiau kaip 2000 karininkų. Akademija įsikūrusi trijose kareivinèse: Klauzevico (Clausewitz), generolo leitenanto grafo von Baudisino (Baudissin) ir Eberto (Ebert). Generalinio štabo akademiją sudaro mokymo, kursų ir aprūpinimo vienetai. Užsieniečiams čia įrengti du skyriai - vienas priklauso NATO šalių atstovams, kitas - šiam aljansui nepriklausančių šalių atstovams. Majoras (dabar Lietuvos kariuomenès vadas, gen. 1tn., 2015) Jonas Vytautas Žukas, anksčiau vadovavęs „Geležinio vilko“ brigados Kauno batalionui, buvo priimtas $i$ antraji skyrių ir buvo pirmasis Lietuvos atstovas Bundesvero vadų akademijoje, kurioje studijavo 1992-1994 m.

Bundesvero vadų akademijos kursai. Bundesvero vadų akademija, vykdydama savo pagrindinę užduotị, rengia aukštos kvalifikacijos štabo karininkus ìvairaus lygmens nacionaliniams ir tarptautiniams štabams. Akademija siūlo per 30 ịvairiausių kursų ir seminarų.

Tris kartus per metus vyksta pagrindinis štabo karininkų kursas. Jo trukmė 14 savaičių. Šiame kurse dalyvauja visi kapitono ir kapitono leitenanto karinị laipsnị turintys karininkai. Beveik 85 proc. karininkų, baigusių ši kursą, vèliau dalyvauja vadovavimo karinemis pajegomis kurse ir apie 15 proc. karininkų tampa kandidatais ị generalinio štabo / admiraliteto kursą.

Nacionalinis generalinio štabo / admiraliteto kursas (LGAN) egzistuoja nuo 
Bundesvero vadų akademijos ịkūrimo dienos. Šis kursas trunka 24 mėnesius ir yra skirtas tik karininkams iš NATO ir ES šalių. 25 proc. LGAN kurso dalyvių sudaro užsieniečiai.

1962 m. ịsteigus tarptautinị generalinio / admirolinio štabo kursą (LGAI), buvo atvertos durys ị Bundesvero vadų akademiją karininkams iš ne NATO ir ES šalių. Užsienio šalių karininkai šiame kurse ne tik įgyja specialybės žinių, bet ir susidaro išsamų vaizdą apie Vokietijos Federacinę Respubliką. Hamburgas kaip tarptautinis miestas ir Vartai ị pasaulį tam sudaro puikias sąlygas. Tarptautinis kursas LGAI baigiasi EURO kursu. Šiame 3 mènesių trukmès kurse karininkai rengiami darbui NATO štabuose. EURO kursas įsteigtas 1996 metais.

Iki 2005 m. Lietuvos karininkai buvo rengiami LGAI ir EURO kursuose. Lietuva dalyvauja LGAI kurse nuo 1993 m. ir EURO kurse nuo $1997 \mathrm{~m}$.

LGAI kurso tikslas - parengti užsienio šalių karininkus tarnauti įvairaus lygmens štabuose. Mokymo metu karininkai supažindinami su Bundesvero sudètimi, struktūra ir uždaviniais. Ruošiami panaudoti karines pajègas taikos, krizių ir karo atvejais. Taip pat suteikiama žinių apie Vokietijos Federacinès Respublikos užsienio ir saugumo politiką.

Lietuvai tapus NATO nare, keitėsi Lietuvos statusas, baigèsi vienas studiju etapas Bundesvero vadų akademijoje ir prasidejo kitas. 2005 m. paskutiniai Lietuvos karininkai baigè dešimties mènesių Tarptautinị generalinio štabo / admiraliteto kursą (LGAI) ir EURO kursą. Nuo 2005 m. Lietuvos karininkai dalyvauja dviejų metų nacionaliniuose generalinio štabo / admiraliteto kursuose (LGAN), kurie skirti tik NATO ir ES šalims.

2005 m. birželio 1 d. Lietuvos Vyriausybè nutarimu Nr. 603 patvirtino naują Karių, pasiųstų stažuotis ar mokytis, tarnybos ir aprūpinimo stažuotės ar mokymosi laikotarpiu tvarkos aprašo redakciją (patvirtinta $1997 \mathrm{~m}$. kovo 27 d. nutarimu Nr. 288), kurioje pateikiamos karių, pasiųstų stažuotis ar mokytis ị Lietuvos mokymo institucijas, tarnybos ir aprūpinimo sąlygos; kariūnų, pasiųstų mokytis ị užsienio karo mokymo įstaigas, tarnybos ir aprūpinimo sąlygos; profesinès karo tarnybos karių, karių savanorių (aktyviojo kariuomenès rezervo prievolininkų), pasiųstų stažuotis ar mokytis ị užsienio mokymo institucijas, tarnybos ir aprūpinimo sąlygos.

Vakaru karo mokyklos rengia kvalifikuotus kuopos, bataliono, štabo vado lygmens karininkus, jie vẻliau dar adaptuojasi, gauna pritaikytą Baltijos gynybos sistemai išsilavinimą Baltijos gynybos koledže (Tartu).

Didelị vaidmenị rengiant ir tobulinant Lietuvos karininkus ir civilius tarnautojus atlieka Baltijos gynybos koledžas (Baltic Defence College - BALTDEFCOL) Tartu (Estijoje).

İkurti Baltijos gynybos koledžą buvo nuspręsta $1998 \mathrm{~m}$. birželio $12 \mathrm{~d}$. Briuselyje Lietuvai, Latvijai, Estijai ir Skandinavijos šalims pasirašius Tarpvalstybini susitarima. BALDEFCOL - bendras Baltijos valstybių projektas, remiamas dar 16 šalių. Tai vienintelis istorijoje karo koledžas, kuris priklauso trims valstybėms - 
Lietuvai, Latvijai ir Estijai. BALTDEFCOL buvo atidarytas $1999 \mathrm{~m}$. vasario mėnesị. $2000 \mathrm{~m}$. birželio $22 \mathrm{~d}$. pirmajai klausytojų laidai įteikti baigimo diplomai, tarp jų ir 8 Lietuvos karininkams.

Šio projekto autorius, buvęs Danijos gynybos atašè Lietuvai, Latvijai ir Estijai, brigados generolas M. H Klemesenas (M. H. Clemmesen) pastebejo, kad Baltijos šalių kariuomenėms labai trūksta mažų šalių gynybos politiką išmanančių, visapusiškai išsilavinusių karininkų, galinčių dirbti nacionaliniuose, brigadų ar aukštesniuose kariniuose štabuose, NATO. Mažoms valstybèms labai brangu karininkus mokyti kitose šalyse. Nė viena NATO šalis nesiimtų išmokyti tiek karininkų. Baltijos valstybėms tiktų pasinaudoti Šiaurès Europos mažųų valstybių karine patirtimi, paremta visuotinès gynybos sistema.

Parengtos mokymo programos pagrindas - individualus studentų darbas ir praktinių užduočių atlikimas. Ši 1999 m. vasario 25 d. Tartu mieste Estijoje atidaryta tarptautinè karinio mokymo įstaiga rengia Baltijos valstybių štabų karininkus, kurie tarnaus savo šaliu gynybos ministerijose, kariuomenių ir tarptautiniuose (pavyzdžiui, NATO) brigados lygmens ir aukštesnio lygmens štabuose, eis gynybos atašè pareigas arba dėstys karinius dalykus nacionalinėse karo akademijose. Baltijos valstybių prašymu Danija skyrè Baltijos gynybos koledžo komendantu (vado$\mathrm{vu}$ ) brigados generolą M. H. Klemeseną. BALTDEFCOL mokymo turinys pritaikytas prie Baltijos regiono geopolitinių ypatumų, turimų karinių pajègų pobūdžio. Mokymo procese stengiamasi kuo daugiau taikyti NATO procedūras ir standartus. Tai skatina Baltijos valstybių kariuomenių sąveikumą su NATO.

Studijuoti koledže karininkai atrenkami pagal reikalavimus, kurie nurodyti Lietuvos Respublikos krašto apsaugos ministro ịsakyme. Su jais dalinių vadai supažindina karininkus, norinčius studijuoti koledže (Žigaras, 2002; Karys, 1999, Nr. 5, (1804): 7; Krašto apsauga, 2015, Nr. 11 (80): 3).

Studijos koledže vyksta anglų kalba. Koncentruojamasi į NATO štabų ir operacinio planavimo procedūras. Koledžą baigę karininkai yra pasirengę dirbti nacionaliniuose pajègų, taip pat NATO štabuose bei daugianacionalinių pajègų štabuose tarptautinèse operacijose.

Kursuose karininkai ir civiliai tarnautojai rengiami vadovauti strateginiu ir operaciniu lygmenimis, dirbti jungtiniuose štabuose ir tarptautinèse organizacijose. Civilių tarnautojų kurso tikslas - suteikti civiliams tarnautojams reikalingų žinių ir gebejjimų vystyti ir ịgyvendinti nacionalinę saugumo ir gynybos politiką civilinèskarinès partnerystès būdu operaciniu ir strateginiu lygmenimis.

Baltijos gynybos koledžas yra vienintelė aukštojo karinio rengimo institucija, kurios dèmesio centre yra mažujų žemyninès Europos šalių saugumo problemos.

Koledže koncentruojamasi ị moderniają karinių konfliktų analizę, bendrų operacijų planavimą ir ateities tendencijų numatymą.

2000-2015 m. koledžą yra baigę daugiau nei 1000 vyresniujų karininkų ir aukštesniojo lygmens civilių pareigūnų iš 39 šalių (Krašto apsauga, 2015, Nr. 10 (297): 11). 


\section{Išvados}

1. Taigi per nepriklausomybès laikotarpi buvo sukurta tobula ir efektyviai funkcionuojanti Lietuvos kariuomenès karininkų rengimo ir jų kvalifikacijos kèlimo sistema. Svarbiauią vaidmenį rengiant karininkus ir keliant jų kvalifikaciją atliko Generolo Jono Žemaičio Lietuvos karo akademija, taip pat Generolo Adolfo Ramanausko kovinio rengimo centras, Lietuvos kariuomenès Sausumos pajègu Juozo Lukšos mokymo centras, Dr. Jono Basanavičiaus karo medicinos tarnyba ir kiti daliniai, kurie rūpinasi karininkų kvalifikacija.

2. Lietuvos karininkai sẻkmingai mokosi ir tobulinasi užsienio šalių karinèse mokymo institucijose. Didelị vaidmenį rengiant ir tobulinant Lietuvos karininkus ir civilius tarnautojus atlieka Baltijos gynybos koledžas, kiti ịvairūs karo ir gynybos koledžai, vadų ir generalinio štabo karininkų kursai ir kt.

3. Tolesniam karininkų rengimui ir jų kvalifikacijos kèlimui buvo įsteigti ịvairūs specializuoti ilgalaikiai ir trumpalaikiai, nuolatiniai ir laikini kursai. Sèkmingai ir produktyviai veikia Jaunesniujų karininkų vadų mokymai (JKVM). Tokie kursai aukštujų mokyklų studentams buvo rengiami Lietuvos didžiojo kunigaikščio Butigeidžio dragūnų batalione Klaipedoje, Generolo Jono Žemaičio Lietuvos karo akademijoje Vilniuje ir Divizijos generolo Stasio Raštikio puskarininkiu mokykloje Kaune.

4. Karininkų rengimu, jų kvalifikacijos kèlimu taip pat rūpinasi ir Lietuvos atsargos karininkų sajunga, karininkų ramovès, karinė spauda ir kt. Ši sistema užtikrina visų lygių karininkų rengimą, formuoja įvairiapusiškai išsilavinusių karininkų korpusą.

\section{Literatūra}

1. Aukštakalnis D., İsteigtas Sausumos pajègų Juozo Lukšos mokymo centras, Krašto apsauga, 2011-08-16-2011-08-31, Nr. 16, (2012), p. 2.

2. BALTDEFCOL užima ypatingą vietą NATO mokymo sistemoje, Krašto apsauga, 2005-06-30-2005-07-14, Nr. 11 (80), p. 3.

3. Balaišis A., Karininkų rengimas Lietuvoje, Karys, 1996, Nr. 1, p. 23.

4. Baltijos gynybos koledže įteikti diplomai dvidešimčiai Lietuvos Karių ir civilių tarnautojų, Krašto apsauga, 2015-05-25 - 2015-06-22, Nr. 10 ((297), p. 11.

5. Baranauskas D., Pažinti - suprasti - bendradarbiauti: JAV politikos stiprinant Europos saugumo sistemą principai, Karys, 1995, Nr. 7, p. 32.

6. Budrys K., Karybos meno ị Vakarus, Karys, 1997, Nr. 9, p. 8-9.

7. Gen. Adolfo Ramanausko karių profesinio tobulinimo centras, Krašto apsauga, 2001-11-23-12-07, Nr. (1) 1, p. 14.

8. Generolo Jono Žemaičio Lietuvos karo akademijos istorinė pažyma ir jos archyvinis fondas 1998-1999 m. m., 2001 m. rugpjūčio 27 d., Generolo Jono Žemaičio Lietuvos karo akademijos archyvas, fondo byla Nr. 14, 1, 1-2. 
9. Generolo Jono Žemaičio Lietuvos karo akademija 1992-2002 (2002), Vilnius: Generolo Jono Žemaičio Lietuvos karo akademija.

10. Jankauskas P., Studijos karo akademijoje, Mokslas ir gyvenimas, 2002, Nr. 1, p. 20-21.

11. Juozo Lukšos mokymo centre pirmaji pusmeti - net 84 kursai, Krašto apsauga, 2012-07-30-2012-08-26, Nr. 14 (237), p. 7.

12. Kariūnai aspirantai pratybose demonstravo savo pasirengimą vadovauti rezervo būriui, Krašto apsauga, 2015-06-23-2015-07-26, Nr. 11 (298), p. 19.

13. Karo akademija rengia karininkus pagal NATO standartus, Krašto apsauga, 2002-02-22-03-07, Nr. 4 (7), p. 17.

14. Karo medicinos tarnybai suteiktas dr. Jono Basanavičiaus vardas, Krašto apsauga, 2008-12-03-2008-12-17, Nr. 21 (150), p. 19.

15. Karpinskas A., Juozo Lukšos mokymo centras rengia kovinès inžinerinès paramos vadovus, Krašto apsauga, 2015-10-04-2015-10-25, Nr. 15 (302), p. 20.

16. Klenauskienė I., Varanavičius D., „Lietuvos kariuomenès mokykla - 25 metai intensyvaus darbo“, Karys, 2015, Nr. 12 (2040), p. 10-11.

17. Krašto apsaugos departamento generalinio direktorius A. Butkevičiaus ịsakymas Nr. 45, 1990 m. gruodžio 29 d. „Dèl Lietuvos Respublikos Karininku kursų įsteigimo“, Krašto apsaugos departamento generalinio direktoriaus įsakymai 1990-1991, ats. red. ir sudar. G. Surgailis, Vilnius: Lietuvos Respublikos krašto apsaugos ministerija, Generolo Jono Žemaičio Lietuvos karo akademija, 2003, p. 34.

18. Krašto apsaugos ministro įsakymas „Dèl Lietuvos aukštosios karo mokyklos įkūrimo“, Nr. 112, 1992-02-25, Krašto apsaugos ministro įsakymai, t. 1, Nr. 222-355, 1992 Nr. 01-479, ats. red. ir sudarytojas G. Surgailis, t. 1, Vilnius: Generolo Jono Žemaičio Lietuvos karo akademija, 2004, p. 175.

19. Kulys Z., Lietuvos karo akademija, Krašto apsauga, Proginis Krašto apsaugos ministerijos laikraštis, 1995 m. balandžio 25 d., Nr. 1 (129), p. 13.

20. Liekis A., Lietuvių karyba ir ginkluotè (iki 1950 m.), (2002), Vilnius: Vilniaus Gedimino technikos universitetas.

21. Lietuvos aukštųjų mokyklų studentai galès tapti karo medikais, Krašto apsauga, 2012-12-15 - 2013-01-04, Nr. 22 (245), p. 30.

22. Lietuvos karininkų rengimo sistemos 15-osios metinès, Krašto apsauga, 2007-07-10-2007-07-24, Nr. 11 (123), p. 16.

23. Lietuvos karo akademija pradès rengti karininkus - visuomenès saugumo specialistus, Krašto apsauga, 2016-01-04-2016-01-17, Nr. 1 (306), p. 23.

24. Lietuvos Respublikos vyriausybės nutarimas „Dèl Krašto apsaugos akademijos steigimo“, Vilnius, 1992 m. birželio 16 d., Nr. 460. [žiūrèta 2015-03-21]. Prieiga per internetą: http://www3.lrs.lt/pls/inter3/dokpaieska.showdoc_1?p_id= $6772 \& p \_t r 2=2$.

25. Lietuvos Respublikos Seimo nutarimas „Dèl Lietuvos karo akademijos įsteigimo“, Vilnius, 1994-01-18, Nr. I-371, Valstybės žinios, 1994 m. sausio 26 d., Nr. 7-103, [žiūrèta 2015-03-30]. Prieiga per internetą: http://www3.lrs.lt/pls/ inter3/dokpaieska.showdoc_1?p_id=5704\&p_tr2=2. 
26. Lietuvos Respublikos Vyriausybès nutarimas Dèl Generolo Jono Žemaičio Lietuvos karo akademijos statuto patvirtinimo“, Vilnius, 1999 m. rugpjūčio 18 d., Nr. 896, Vyriausybès žinios, 1999 m. rugpjūčio 13 d., Nr. 69-2196, [žiūrèta 2015-03-24]. Prieiga per internetą: http://www3.lrs.lt/pls/inter3/dokpaieska. showdoc_1?p_id=85019\&p_query=karo\%20akademijos\%20statutas\&p_tr2=2.

27. Lietuvos Respublikos Vyriausybès nutarimas, „Karių, pasiųstų stažuotis ar mokytis, tarnybos ir aprūpinimo stažuotès ar mokymosi laikotarpiu tvarkos aprašas“, Vilnius, 2005 m. birželio 1 d. nutarimo Nr. 603, redakcija, Valstybės žinios, 2005-06-04, Nr. 70 - 2534. [žiūrèta 2015-04-22]. Prieiga per internetą: http:// www3.1rs.1t/pls/inter3/dokpaieska.showdoc_1?p_id $=256867 \& p \_t r 2=2 \mathrm{~m}$.

28. Lietuvos Respublikos karine strategija, patvirtinta Lietuvos Respublikos krašto apsaugos ministro $2012 \mathrm{~m}$. lapkričio 22 d. ịsakymu Nr. V-1305. [žiūrèta 2015-03-30]. Prieiga per internetą: http://www.kam.lt/lt/gynybos_politika_490/ aktualus_dokumentai_492/strateginiai_dokumentai_494.html.

29. „Lietuvos Respublikos piliečių rengimo valstybès gynybai strategija“. Patvirtinta Lietuvos Respublikos krašto apsaugos ministro $2015 \mathrm{~m}$. rugpjūčio $19 \mathrm{~d}$. ìsakymu Nr. V-849. [žiūrèta 2016-01-31]. Prieiga per internetą: http://www.kam.lt/ 1t/gynybos_politika_490/aktualus_dokumentai_492/strateginiai_dokumentai_494. html.

30. Mondeikis M., Lietuvos karo akademijos tarptautinio bendradarbiavimo gairès, Krašto apsauga, 2002-06-07-06-13, Nr. 12 (15), p. 7.

31. Paladis A., Baltijos gynybos koledžo BALTDEFCOL inauguracija, Karys, 1999, Nr. 5, (1804), p. 7.

32. Paramediko kursus baigè penkioliktoji laida, Krašto apsauga, 2015-04-27-2015-05-10, Nr. 8 (295), p. 11.

33. Prasideda priemimas i jaunesniųų karininkų vadų mokymus, Krašto apsauga, 2016-01-04-2016-01-17, Nr. 1 (306), p. 11.

34. Reformuojant Karo medicinos tarnybą bus atsisakoma didžiosios dalies pirminès sveikatos priežiūros paslaugų, Krašto apsauga, 2012-07-02-2012-07-15, Nr. 12 (235), p. 20.

35. Surgailis G., Lietuvos karo akademija per 10 metų, Krašto apsauga, 2002-06-07-06-13, Nr. 12 (15), p. 3.

36. Vaičeliūnas A., Kam būsimajam NATO karininkui magistro diplomas, Karys, 2001, Nr. 10-11 (1859-1860), p. 15.

37. Vaitkaitis A., Karininkų rengimas atkūrus Lietuvos nepriklausomybę (1990-1992 metai), Karys, 2012, Nr. 5 (1998), p. 12.

38. Vizbaras B., Puskarininkių mokykla, Krašto apsauga. Proginis Krašto apsaugos ministerijos laikraštis, 1995 m. balandžio 25 d., Nr. 1 (129), p. 13.

39. Žigaras F., Baltijos šalys: saugumas ir gynyba 1990-2002 (2002), Vilnius: Generolo Jono Žemaičio Lietuvos karo akademija.

40. Žukas J. V., Šalies gynyba - kiekvieno mūsų pareiga. Kaip ją atliksime?, Krašto apsauga, 2014-12-15-2014-01-04, Nr. 20 (287), p. 22. 


\title{
LITHUANIAN MILITARY OFFICERS' TRAINING AND THE TRAINING SYSTEM DEVELOPMENT IN THE PERIOD OF 1990-2015
}

\author{
Assoc. Prof. Dr. Feliksas Žigaras \\ The General Jonas Žemaitis Military Academy of Lithuania
}

\section{Summary}

During the Independence period, a perfect and effectively functioning Lithuanian military officers' training system was developed. The General Jonas Žemaitis Military Academy of Lithuania, General Adolfas Ramanauskas Warfare Training Centre, Juozas Lukša Land Forces Training Center, MD Jonas Basanavičius Military Medical Service, Lithuanian Navy Training Center in Klaipeda and other units of the Lithuanian Armed Forces have been playing the biggest role in military officers' training and training system development.

Lithuanian military officers successfully study and train at foreign military education institutions. The Baltic Defence College and other military and defence colleges, courses for commanders and general staff officers assume a great role in training Lithuanian military and civil officers.

Various long-term and short-term, continuous and temporary courses were established for further military officers' training. The courses for younger military commanders are successful and productive. Such courses for higher school students have been organized at the Lithuanian Grand Duke Butigeidis Dragoon Battalion in Klaipeda, The General Jonas Žemaitis Military Academy of Lithuania in Vilnius and Division General Stasys Raštikis Lithuanian Armed Forces School in Kaunas.

The Lithuanian Union of Reserve Officers, officers' clubs, military press and others also participate in the training process. The system ensures military officer training of all levels and forms comprehensively educated military corps. 


\section{AUTORIAUS LYDRAŠTIS}

Autoriaus vardas, pavardè: Feliksas Žigaras

Mokslo laipsnis ir vardas: docentas, daktaras

Darbo vieta ir pareigos: Generolo Jono Žemaičio Lietuvos karo akademijos Politikos mokslų katedros docentas

Autoriaus mokslinių interesų sritys: Lietuvos tarptautinis bendradarbiavimas; Lietuvos, Latvijos ir Estijos santykiai; pilietinio ugdymo raida, patirtis, Lietuvos kariuomenès problemos, jų sprendimo būdai; Lietuvos kariuomenès karininkų rengimas (1919-1940 m.); Lietuvos kariuomenès karininkų rengimas (1990-2015 m.)

Telefonas ir el. pašto adresas: 861284 775; feliksas.zigaras@yahoo.com

\section{AUTHOR'S COVER LETTER}

Author's name and surname: Feliksas Žigaras

Academic degree and name: Associate Professor, Doctor

Workplace and position: The General Jonas Žemaitis Military Academy of Lithuania, Department of Political Science, Associate Professor

Author's research interests: international cooperation of Lithuania, relationship among Lithuania, Latvia and Estonia, civic education development, experience and problems of the Lithuanian Armed Forces and their solutions, Lithuanian officers' training in the period of 1919-1940, Lithuanian officers' training and the training system development in the period of 1990-2015

Telephone and e-mail address: +370 61284 775; feliksas.zigaras@yahoo.com 